\title{
Kurumsal Kuram Açısından Örgütsel Dil i̇le Örgütsel Meşruiyet İlişkisi: Örgütler Dil Aracılığıyla Meşruiyeti Nasıl Elde Eder? ${ }^{1}$
}

\author{
Salih Arslan ${ }^{2}$ \\ Recai Coşkun ${ }^{3}$
}

Kurumsal Kuram Açısından Örgütsel Dil ile Örgütsel Meşruiyet ilişskisi: Örgütler Dil Aracılığıyla Meşruiyeti Nasıl Elde Eder?

\section{Öz}

Bu çalışma örgütlerin yapı ve pratiklerinin kurumsal çevreye uygun olmadığı durumlarda bile uyumlu görünümü vermeyi başararak nasıl meşruiyet elde edebildiklerini kurumsal kuram yaklaşımıyla açıklamayı amaçlamaktadır. Bu nedenle "örgütsel dilin örgütsel meşruiyetteki rolü kurumsal kuramla açıklanabilir mi?" sorusunun cevabını aramaktadır. Araştırmada meşruiyet hükmünü veren değerlendiriciler, meşruiyet arayan örgütler ve değerlendiricilerde bu hükmü oluşturmak için örgütler tarafından kullanılan dil stratejileri incelenmiş ve analiz edilmiştir. Örgütlerin kurumsal yapının sembol ve kelimeleriyle inşa ettikleri dili değerlendiricilerle iletişimlerinde kullandıkları ve böylelikle değerlendiricilerin pragmatik, bilişsel, ahlaki, değersel ve duygusal yönlerini etkileyerek meşruiyet hükmü oluşturdukları sonucuna ulaşılmıştır. Bu sonuç örgütsel dil ile örgütsel meşruiyet arasındaki ilişkinin her ikisinin de kurumsal olgular olması sebebiyle kurumsal kuram bakış açısıyla daha anlaşıı ıir şekilde açıklanabileceğini göstermiştir.

Anahtar Kelimeler: Örgütsel Dil, Örgütsel Meşruiyet, Kurumsal Kuram, Örgütsel Dil Örgütsel Meşruiyet Ilişkisi
The Relationship Between Organizational Language and Organizational Legitimacy In Terms of Institutional Theory: How the Organizations Gain Legitimacy Through Language?

Abstract

This study aims to explain through institutional theory how organizations can acquire legitimacy by achieving harmonious appearance even when the structures and practices of organizations don't conform to the institutional environment. Therefore it is seeking the answer of the question that "the role of organizational language in organizational legitimacy can be explained by institutional theory?". In the investigation have been examined and analyzed that legitimacy seeking organizations, evaluators who have given legitimacy and the language strategies used by organizations to create this provision in evaluators. They have come to the conclusion that the organizations use in communicating with the evaluators language that they build with the symbols and words of the institutional structure, thus constituting a provision of legitimacy by affecting the pragmatic, cognitive, moral, value and emotional aspects of evaluators. This result shows that the relationship between organizational language and organizational legitimacy can be explained more clearly in terms of institutional theory because both are institutional phenomena.

Keywords: Organizational Language, Organizational Legitimacy, Institutional Theory, Relationship Between Organizational Language and Organizational Legitimacy

\section{Giriş}

Meşruiyet kurumsal kuram, kaynak bağımlılığı kuramı ve örgütsel ekoloji gibi örgüt teorilerinin ana kavramlarından biridir ve araştırmacılar bu kavrama fazlaca dikkat çekmişlerdir (Deephouse ve Carter, 2005: 229; Bitektine, 2011: 152). Fakat kurumların gerekli bir özelliği olarak görüldüğü için kurumsalcı çalışmalarda hayati önemde olduğu düşünülmektedir (Tost, 2011: 686). Dil ise kurumsalcı analizde önceleri görmezden gelinse de (Phillips, Lawrence ve Hardy,

\footnotetext{
${ }^{1}$ Bu çalışma Sakarya Üniversitesi Sosyal Bilimler Enstitüsü İşletme Anabilim Dalı’nda Prof. Dr. Recai Coşkun danışmanIığında Salih Arslan tarafından “Örgütsel Meşruiyet İle Örgütsel Dil Arasındaki İlişkinin Kurumsal Kuram Açısından İncelenmesi" ismiyle yazılan doktora tezinden türetilmiştir.

${ }^{2}$ Doktora öğrencisi, Sakarya Üniversitesi, Sosyal Bilimler Enstitüsü, salih.arslan1@ogr.sakarya.edu.tr.

${ }^{3}$ Prof. Dr., Sakarya Üniversitesi, İşletme Fakültesi, İşletme Bölümü, coskun@sakarya.edu.tr.
} 
2004: 638) sonraları dilsel etkileşimlerin daha fazla çalışılması (Powell ve Colyvas, 2008: 279) ve dilin bağdaştırıcı rolüne dikkat edilmesi (Hirsch, 1997: 1719) yönünde öneriler yaygınlaşmıştır. Bunun sonucunda dil ve anlamın önemi fark edilmiş (Phillips ve Oswick, 2012: 438) ve örgütsel dil daha fazla ilgi görmeye başlamıştır (Scott, 2008; 435). Bu süreçte kurum ve dil ilişkisini araştıran birçok çalışma yapılmış (Harmon, Green ve Goodnight, 2015: Cornelissen vd., 2015: Bitektine ve Haack, 2015: Green ve Li, 2011: Tost, 2011: Etzion ve Ferraro, 2010: Lawrence ve Phillips, 2004) ve zamanla söylemsel kurumsalcılık olarak nitelenen dil temelli bir yaklaşım ortaya çıkmıştır (Green ve Li, 2011: 1670). Bu araştırmada, kurumsalcı analizde ortaya çıkan bu yaklaşım takip edilmiş ve değerlendirmeler onun bakış açısıyla yapılmıştır.

\section{Teorik Çerçeve: Çalışmanın Temel Problemi, Yöntemi ve Katkısı}

Çalışma, yukarıda bahsedilen yaklaşımdan hareketle örgütsel dilin kurumsal çevrede örgütü nasıı meşrulaştırdığını açıklamayı amaçlamaktadır. Bu doğrultuda aşağıdaki araştırma sorularının cevapları aranmıştır:

Araştırma Sorusu-1: Örgütsel dil örgütsel meşruiyetin oluşumunda rol oynar mı?

Araştırma Sorusu-2: Örgütsel dilin örgütsel meşruiyetin oluşumunda rol oynadığı iddiası kurumsal kuramla çelişir mi?

Örgütsel dilin örgütsel meşruiyetteki rolünün kurumsal kuram bakış açısıyla analizi araştırmanın temel problemini oluşturmaktadır. Çünkü örgütsel dil gibi örgütsel analizde daha çok stratejik anlamda kullanılan bir kavram ile meşruiyet gibi toplumsal bir olgunun ilişkisini kurumsal kuramın geleneksel bakış açısıyla açıklamak pek kolay değildir. Özellikle kurumsal kuramın teorinin merkezine koyduğu "kanıksanmış yapı ve eylem" varsayımıyla hareket edildiğinde bu iyice zorlaşmaktadır. Örgütlerin serbestçe dil stratejilerini belirlediği varsayımından hareket edildiğinde ise kurumsal teorinin oldukça dışına çıkılacaktır. Bu nedenle kurumsal kuramın temel bakış açısı ve iddialarıyla bu ilişkinin açıklanıp açıklanamayacağı çalışmanın temel problemi olarak görünmektedir.

Bu problemi çözümleyebilmek için öncelikle meşruiyet kavramının ve sonrasında dil stratejilerinin nasıl ele alınması gerektiğinin açıklığa kavuşturulması gerekir. Örgütsel teori literatüründe örgütsel meşruiyet, stratejik ve kurumsal olarak ayrılır (Suchman, 1995: 575). Ancak meşruiyetin uyulması gereken belirli standart yapıların varlı̆̆ını ön koşul olarak gerektirmesi (Aldrich ve Fiol, 1994: 645-646) bu ayrımın mantığını sorgulamaya yöneltmektedir. Gerçi Zucker (1991: 105) araştırmaların benzer kurumsal çevreye sahip örgütlerin farklı stratejik cevaplar verdiklerini gösterdiğini söylemektedir ama Powell'a (1991: 194) göre farklı strateji seçme imkânı kurumsal çevrenin sunduklarıyla sınırlıdır. Bu nedenle Green ve Li'ye (2011: 1664) göre dil stratejileri de örgütsel alanda yaşanan bağımlılık ve anlam karmaşası nedeniyle ancak kurumsal çevredeki alternatifler arasından seçilebilir. Lawrence (1999: 167) ise bu stratejileri "kurumsallaşmış stratejiler" olarak niteler.

Kurumsallaşmış olarak nitelenen söylem stratejileri kurumsal çevrenin işaret, kelime ya da sembollerinden oluşur. Çünkü kurumsal olgular kolektif temsil yeteneğine sahiptir ve kolektif temsil kamusal olma, uylaşıma dayanma ve bir araca gereksinim duyma özellikleri taşır (Searle, 2005: 101). Kurumsalcı teorisyenler Meyer ve Rowan (1977: 349) da meşruiyetin ancak kurumsal kurallarla uyumlu yapısal kelimeler sayesinde elde edilebileceğini söyler. Aksi takdirde zaten kurumsal çevre tarafından anlamlandırılamayacak ve onaylanmayacaktır (Tolbert ve Zucker, 1996: 177). Küreselleşen ve örgütlerin giderek uluslararası çevreyle daha fazla ilişki kurduğu bir dönemde, oluşturdukları dilin de bu çevrelerin niteliğine göre değişmesi kaçınılmazdır (Vaara 
ve Tienari, 2011: 387). Fakat bütün örgütlerin küresel bir mantığa sahip olduğu iddia edilemez. Bu nedenle bazı örgütlerin yerel ve kısa süreli, diğer bazı örgütlerin ise sürekli ve evrensel bir bakış açısına sahip oldukları öne sürülebilir (Zucker, 1991: 101). Di Maggio'nun (1997: 273) evrensel ve topluma özgü şemalar ayrımı, bu tip örgütlerin zihin yapılarını anlamamıza yardım eder. Şema ve dil ilişkisinden yola çıkıldığında topluma özgü şemaya sahip örgütün evrensel söylem üretmekte, evrensel şemaya sahip örgütün ise toplumlara özgü dil geliştirmekte zorlandığı söylenebilir. Fakat bu bakış açısı, günümüz örgütlerinin karmaşık dil stratejilerini açıklamada yetersiz kalır. Çünkü Brown ve Humphreys (2006: 234) örgütlerdeki söylem yapılarının tekçi değil, çoğulcu ve çok sesli olduğunu söylemektedir.

Dil stratejilerinin kurumsal olduğu ve örgütlerin bulundukları kurumsal yapıya göre dil stratejisi belirledikleri şeklindeki iddiaları temellendirebilmek için kurumsal kuramın “örgütlerin yapıyı kusursuz kanıksadı̆ıı" varsayımını esnetmek gerekir. Zaten bu varsayım kurumsal analizde ciddi şekilde eleştirilmiştir (Hirsch, 1997: 1715). Collins (1981: 985) günlük hayatta mikro davranışların rasyonel karar verme ve bilişsel modelleri takip etmediğini, sosyal etkileşimin ise kanıksanma ile açıklanamayacak örtük anlam ve uzlaşılara bağlı olduğunu söyler. Bundan dolayı bu çalışmada "kanıksanma" varsayımına temkinli yaklaşılmış ve literatürde kurumsalcılık ile dili uyumlaştırmaya çalışan araştırmalardan yararlanarak, dil stratejilerinin baskın kurumsal yönleri teorik düzlemde açıklanmaya çalışılmıştır. Ancak örgütlerin kurumsal çevreye uyumları, içselleşme ya da niyete bağlı olarak gerçekleşebildiği (Bitektine ve Haack, 2015: 60) için "kanıksanma" kavramı tamamen ihmal edilmemiştir. Çünkü niyet amaçlı eyleme referans ederken, içselleşme zorunlu olarak kanıksanmayı içermektedir. Bu durum örgütsel alanda, bir yandan kanıksanmanın görmezden gelinemeyeceğini gösterirken diğer yandan örgütlerde çoklu şematik yapıların varlığına dair iddiaları (Friedland ve Alford, 1991: 243; Sewell, 1992: 8) güçlendirmektedir.

Kurumlar, kültürel ve söylemsel boyuta sahiptir (Meyer, 2008: 791) ve belirli kurallar üzerine temellenmiş ortak bir söylemin içine gömülüdür (Jepperson, 1991: 152). Bu ortak söylem biçimi dilsel formlar şeklinde hesap verebilmeyi sağlayan nesnel kurallar olarak işlev görür (Zucker, 1991: 85). Bu formlar örgütlerin değerlendiricilerce anlaşılmasını sağlarken, meşruiyet elde edilmesine de yardımcı olur. Ancak sosyal topluluklar arasında kurum ve söylem açısından farklılıklar olabilir. Tek bir şematik yapıya sahip olan örgütün bu farklılıklarla başa çıkabilmesi zordur. Oliver (1992: 565) çoklu şemaların, örgütlerin şartlara bağlı olarak alternatif sergileme yeteneklerini gösterdiğini, Creed vd. (2002: 492) ise örgütlerin meşruiyet konusunda çoklu kültürel söylemde bulunabildiklerini belirtir. Bu nedenle örgütlerin çoklu şematik yapılara sahip olabildiği ve farklı sosyal topluluklar için ayrı dil stratejileri geliştirdiği öne sürülebilir. Örgütlerin çoklu kültürel söylem ve kurumsallaşmış stratejilerle meşruiyet elde ettiklerini iddia eden bu çalışma, meşruiyet ve dil ilişkisinin kurumsal yönünü göstererek teorik, örgütlerin ne tür dil stratejileriyle meşruiyet elde edebildiklerini açıklayarak pratik düzeyde literatüre katkı yapmayı amaçlamaktadır. Bunun için başlıca meşruiyet hükmünü veren değerlendiriciler, meşruiyet arayan örgütsel yapıcılar ve ikisi arasındaki etkileşimi sağlayan örgütsel dil konuları ele alınacak ve tartışılacaktır.

\section{Meşruiyetin Değerlendiricileri}

Meşruiyet kavramı literatürde, bir örgütün toplumdaki algısı olarak tanımlanır (Boyd, 2000: 345). Fakat bu algı, örgütler tarafından kazanılan bir varlık değil, örgütün çevresindeki bütün değerlendirici aktörler (Ruef ve Scott, 1998: 880) tarafından düşünce ve eylemde verilen bir değerdir (Harmon vd., 2015: 76). Bu aktörler bir örgütün sosyal özellikleri, eylemleri, sosyal, politik ve ekonomik çıktıları hakkında hüküm verir ve bu hüküm genelde değerlendiricinin algı 
ve inancıyla ilişkilidir (Tost, 2011: 687). Sosyal analizde aktör kavramı, bireysel ve kolektif olmak üzere iki ayrı biçimde incelenir.

Bireysel değerlendiriciler algılayan, analiz eden ve hüküm veren kişisel aktörler iken kolektif değerlendiriciler örgütler, meslek birlikleri, çıkar grupları ve hükümetler gibi kolektif hüküm veren aktörlerdir (Bitektine ve Haack, 2015: 50). Bireyler, örgütsel eylemin meşruiyeti hakkında değerlendirme yapar ancak bağlamın tanımı konusunda uzlaşı sağlanmıştır. Kolektif seviyede ise kurumsal bağlamı tanımlayan daha derin değerlendirmeler söz konusudur (Harmon vd, 2015: 77). Fakat her iki seviyede de değerlendiriciler hem kanıksanmış ve kabul edilmiş beklentilere sahiptir (Golant ve Sillince, 2007: 1152) hem de farklı değerlendirici gruplarının çıkarları, kriterleri ve standartları farklılık gösterebilir (Ruef ve Scott, 1998: 880). Meşruiyet algısı ve inancı oluşturmak isteyen örgütler dil stratejilerini geliştirirken, bu beklenti ve farklılıkları dikkate almak zorundadır.

Meşruiyet ve değerlendiricilerin beklentisi arasındaki ilişkiye odaklanan "statü beklentileri yaklaşımı" meşruiyeti, kültürel inançların belirlediği kişiler arası statü hiyerarşisi tarafından şekillendirilen bir süreç olarak görür (Ridgeway ve Berger, 1986: 603). Bir yere atıf yapılarak oluşan bu inançlar hem etkileşime yol gösterir hem de farklı bireyler için güçlü beklentiler oluşturur (Powell ve Colyvas, 2008: 287). Meşruiyeti güç ve prestij düzeninde statü ve pozisyon arasındaki ilişkide arayan bu yaklaşıma göre, statü özellikleri özel ve genel olmak üzere iki tip beklenti meydana getirir. Özel beklentiler bireysel, genel beklentiler kolektiftir. Meşruiyetin elde edilmesi bu beklentilerin karşılanma düzeyi ile ilgilidir (Berger vd., 1998: 381). Bitektine'e (2011: 151) göre meşrulaşmaya başlayan örgüt, zamanla tanınır ve statü kazanır. Green ve Li (2011: 1663) de meşruiyette tanınma ve prestij algısının önemli olduğunu düşünür. Ancak Deephouse ve Carter'a (2005: 350) göre, tanınmışlık ve meşruiyet aynı şey değildir. Çalışmalarında örgütsel performansın tanınmışlığı artırıcı etkisini görmelerine rağmen meşruiyete etkisine yönelik bir bulguya rastlamadıklarını belirtir. Fakat meşruiyetin değerlendiricilerle ilgili bir durum olduğu yönündeki görüşe katılır.

Kurumsalcı geleneğin daha önceki çalışmalarında da, değerlendiricilerin meşruiyet elde etmedeki rolü vurgulanmıştır (Scott, 1991: 169; Suchman, 1995: 596). Çevresel değerlendirmenin, sosyal kontrolün kamusal göstergesi olduğu ve meşruiyeti açıklayabileceği ifade edilmiş (Meyer ve Rowan, 1991: 58-59) ve örgütlerin meşruiyet süreçlerinde manipülasyon yaparken değerlendiricilerle etkileşim halinde olduğu belirtilmiştir (Ruef ve Scott, 1998: 900). Fakat bu etkileşimin hangi seviyede ve nasıl analiz edileceği yeterince açık değildir. Grant, Keenoy ve Oswick'e (2001: 11) göre genel olarak örgütsel konular, mikro seviyede örgütsel paydaşların değer ve motivasyonları üzerinden, kişiler arası meso seviyede müzakere, çatışma, norm ve roller üzerinden, makro seviyede ise baskın paradigma, kurumsal pratikler ve kolektif sosyal perspektif açısından analiz edilir. Kurumsalcılı̆ın ana akım teorisyenleri Jepperson ve Meyer (2011: 60) ise yukarıdaki sınıflandırmaya benzer şekilde bireysel, sosyo-örgütsel ve kurumsal olmak üzere üç farklı örgütsel analiz seviyesi tanımlar. Fakat Bitektine ve Haack'a (2015: 49-50) göre meşruiyeti anlamada analiz seviyeleri kadar bu seviyeler arasındaki ilişki de önemlidir. Ancak kurumsalcılar, seviyeler arası etkileşime çok az dikkat etmişlerdir. Oysaki bireylerin davranışlarını sergilediği makro seviye kurumsal süreçleri anlamada mikro ve makro analiz seviyeleri arasındaki etkileşimi dikkate almak ve açıklamak gerekir. Aslında Jepperson ve Meyer de (2011: 68) bilimsel açıdan hem saf atomismin (bireyselcilik) hem de saf holizmin (kurumsalcılık) kurgu olduğunu ve tek başlarına sosyal bilim analizlerini saptırarak verimsizleştireceğini düşünmektedir. Fakat onlar bir konuya ilişkin seviyeler arasındaki etkileşimin analizini değil, analizin ayrı seviyelerde 
yapılması gerektiğini kastetmektedir. Çünkü doğrudan makro - makro ilişkilerin ampirik olarak sunulabilmesine karşın, makro - mikro ilişkilerin günlük sosyolojik açıklama çabalarıyla doğrudan gösterilmesinin zor olduğunu düşünmektedir (Jepperson ve Meyer, 2011: 55).

Makro kurumların mikro süreçlerle açıklanabileceğini düşünen DiMaggio (1997: 282) ise kurumsallaşmış kültürel süreçler üzerine mikro yaklaşımın uyumlaştırılmasını önermektedir. Tost (2011: 686) ise bu bakış açısına uygun şekilde, makro kolektif seviye bir kavram olan meşruiyetin mikro seviye dinamiklerini anlamanın önemli olduğunu belirtir. Bu yaklaşımın mantığı kolektif aktörün bireysel aktörlerden oluştuğu kabulüne dayanmaktadır. Bu nedenle kolektif aktörün algı ve düşüncesini anlayabilmek için bireysel aktörlerin algı ve düşüncesinin analiz edilmesi gerektiğini savunmaktadır. Bu bakış açısından meşruiyet, bireylerin tek başına onayından bağımsız bir şekilde örgütlere yapılan bir atıf olarak görülmekle birlikte, bireylerin öznel hükümlerinin zamanla nesnelleşerek toplumsal bir algıya ve kolektif bir seviyeye dönüştüğü kabulüne dayanmaktadır (Bitektine ve Haack, 2015: 50). Bu nedenle yaklaşıma göre kolektif seviye meşruiyet ile sosyal gerçeklik temelde birleşir ve bireyler arası etkileşimin etkisiyle davranışa yol gösterir (Tost, 2011: 686). Bundan dolayı kolektif seviye bir kavram olan meşruiyetin oluşumu bireyler arası etkileşimin sonucu olarak değerlendirilebilir.

Bu noktadan hareket eden Bitektine ve Haack (2015: 51) yaklaşımın mantığını takip ederek hem makro seviyede "kolektif aktörlerin sezgileriyle verdiği meşruiyet hükümlerini" hem de mikro seviyede "bireylerin zihinsel eylemini" ve bu "seviyeler arasındaki etkileşimi" meşruiyetin değerlendiricileri açısından analizinin merkezine koyar. Onun bu girişiminin teorik temeli kurumsalcı gelenekte önceden atılmıştır. Her ne kadar Jepperson ve Meyer (2011: 55) gibi ana akım kurumsalcılar, çoklu seviye açıklama yöntemiyle mikro seviyeden bağımsız makro seviye nedensel bir açıklama yapılmasını önerse de, farklı düşünen kurumsalcı teorisyenler yok değildir. Mesela Powell ve Colyvas (2008: 282) makro unsurların açıklanmasında mikro unsurların analize dâhil edilmesi gerektiğini söylerken, Zucker de (1991: 85-87) makro yapıların oluşumunda mikro unsurların ve iletişimin rolüne vurgu yapmaktadır. Habermas (2001: 71) da mikro seviyede öznel dünyayla makro seviyede nesnel dünya arasındaki bağlantıyı "iletişimsel eylemin" sağlayacağı görüşündedir. Fakat çoklu seviye analiz ile seviyeler arası etkileşim birbirinden farklıdır. Wiley'e (1988: 260) göre çoklu seviye analiz sadece makro - mikro problemini açıklamada daha kapsayıcı olduğu ve seviyeler arası karşılaştırma yapmaya daha fazla izin verdiği için tercih edilebilir. Yoksa bireysel meşruiyet hükümleri gibi mikro unsurların sosyal etkileşimle makro seviyede kolektif meşruiyet hükmüne dönüştüğünü göstermede kullanılamaz.

Çünkü dil ile gerçekleştirilen sosyal etkileşimin, makro kolektif yapıların oluşumundaki rolü inkâr edilemese de (Searle, 2005: 83-84) sosyal etkileşim alanlarında ancak uzun dönemde yaşam biçiminin rasyonelleşebileceği ve kurumsal yapıların ortaya çıkabileceği (Habermas, 2001: 69) görüşü daha akla yatkındır. Bu nedenle örgütsel alanda bir anda ortaya çıkan durumların sosyal etkileşim yoluyla kısa sürede kolektif hükme dönüştüğü ve meşruiyet kazandığını iddia etmek zordur (Aldrich ve Fiol, 1994: 645). Kolektif hüküm zamanla oluşur ve bu zaman aralığı hükmün niteliğine göre değişir. Bu nedenle örgütler tek tek bireyleri etkileyerek

Zamansal boyut dikkate alındığında, örgütlerin dil stratejilerini göreceli olarak uzun zaman sonunda elde edilebilecek bir sonuç üzerine kurabilecekleri kolaylıkla iddia edilemez. Çünkü onlar belirli ve kısıtlı bir sürede meşruiyet elde etmeye ihtiyaç duyar. Bu nedenle bireysel hükümlerin kolektif hükümlere dönüşmesine yönelik tespit, meşruiyet açısından kullanılabilir açıklayıcı bir yaklaşım olarak görünmemektedir. Fakat Bitektine ve Haack'ın (2015: 51) meşruiyeti çoklu seviye değerlendiriciler üzerinden açıklayan bakış açısı takip edilebilir. Bu yaklaşım Harmon 
vd.'nin (2015: 77) "içsel söylem stratejileri" ve "kolektif söylem stratejileri" ayrımı ile bir arada değerlendirildiğinde, meşruiyetin bireysel ve kolektif olmak üzere iki seviyede analiz edilebileceği, örgütlerin içsel söylem stratejileriyle mikro bireysel değerlendiriciye, kolektif söylem stratejileriyle makro kolektif değerlendiriciye yönelik meşruiyet arayışında olduğu varsayılabilir. Böylelikle meşruiyetin değerlendiricisi ve yapıcısı arasındaki strateji ilişkisi de kurulmuş olur.

Bu ilişkinin detaylıca incelenebilmesi için öncelikli olarak değerlendiricide meşruiyet hükmünün nasıl oluştuğunun açıklanması gerekir. Daha önceki çalışmalar örgütlerin, değerlendiricilerin biliş ve inançlarında yaptıkları dönüşümde söylemin önemine değinmişlerdir (Aldrich ve Fiol, 1994: 651). Illetişim ve etkileşim süreçleriyle oluştuğu kabul edilen meşruiyette, değerlendiricilerin bilişsel yapıları ve hüküm verme biçimleri önemlidir (Bitektine ve Haack, 2015: 50). Bu süreçte dil ya da söylemin, değerlendiricilerin bilişsel çıktılarını doğrudan şekillendirdiği iddia edilebilir (Cornelissen vd., 2015: 14). Harmon vd.'ne (2015: 77) göre değerlendiricinin meşruiyet hükmü iki farklı seviye ile ilişkilidir. İçsel seviyede söylem, değerlendiricinin verili bağlamda meşruiyet hükmünü şekillendirir ve yansıtır. Kolektif seviyede söylem ise değerlendiricinin kendi bağlamının meşruiyeti hakkındaki hükmünü şekillendirir ve yansıtır. Bu nedenle söylemin bireysel anlamda bilişsel yapı, kolektif anlamda toplumsal yapıyla uyumu önemlidir. Böyle bir uyum sağlanırsa meşruiyet örgütsel dil aracılığıyla bilişsel bir çıktı ya da hüküm olarak var edilir. Değerlendirici tarafından kanıksanmış olan bu hüküm bilişsel meşruiyet olarak nitelenir. Haack vd. (2014: 636) bu hükmün oluşmasında keşif ve sezgilerin sağladığı zihinsel kısayolun önemli olduğunu düşünür ve bunu "sezgisel hüküm" olarak tanımlar. Meşruiyet hükmü verilirken değerlendirici birçok boyuta birden dikkat eder ve çok yönlü olarak etkilendiği şartlar altında hükmü oluşur. Meşruiyet sürecinde bu boyutların bir kaçı ya da tamamı eş zamanlı bir şekilde değerlendirilir (Tost, 2011: 694).

İkinci olarak önemli görünen ise dil stratejilerinden değerlendiricilerin aynı düzeyde etkilenip etkilenmediğidir. Bireysel ve kolektif aktörler, örgütün çevresiyle kurduğu iletişimin çerçevesine ve örgütsel söylemin sonuçlarına bakarak değerlendirme yapar (Bitektine, 2011: 151). Illetişime katılan değerlendiricilerde aynı düzeyde ortak bilişsel anlamın oluşması oldukça zordur. Çünkü etkileşimde anlaşmazlık, belirsizlik ve heterojenlik toplumun doğası gereği muhtemeldir ve karmaşıklık yaratır (Cornelissen vd., 2015: 14). Bu nedenle örgütlerin meşruiyeti sağlamak için yaptığı açıklamaların, hem makro anlamda kurumsal yapı ile hem de değerlendiricinin günlük hayatının gerçek deneyimi ile uyumlu olması gerektiği öne sürülür (Suchman, 1995: 582). Ancak bu şekilde bireysel ve kolektif değerlendiricilerde meşruiyet hükmünün oluşması sağlanabilir. Tost (2011: 693-694) değerlendiricinin meşruiyet hükmüne üç boyutta yaklaşır. İlki araçsal boyuttur ve değerlendiricinin içselleştirdiği bireysel amaçlarla uyumunu dikkate alır. İkincisi ilişkisel boyuttur ve değerlendiricinin sosyal kimliğini ve içsel değerlerini dikkate alır. Üçüncüsü de ahlaki boyuttur ve değerlendiricinin ahlaki değer ve etik ilkelerini dikkate alır. illki pragmatik meşruiyeti, ikincisi bilişsel meşruiyeti, üçüncüsü ise ahlaki meşruiyeti sağlar. Bu şartlar altında gerçekleşen iletişim eylemi, bir yönüyle de meşruiyetin yapısını yansıtmış olur (Heracleous ve Barret, 2001: 757). Fakat toplumun geneli ile politikacılar, yöneticiler, akademisyenler, aktivistler ve gazeteciler arasında meşruiyet algısı konusunda bir farklılaşma görülür. Haack vd. (2014: 639) bunu "değerlendirici" ve "sezgici" kavramlarıyla açıklamaya çalışır. Bilişsel farklılıklardan kaynaklanan bu durum değerlendiricilerin örgütsel dil stratejilerinden niçin farklı düzeyde etkilendiklerini de anlamamıza yardımcı olur.

DiMaggio (1997: 269-271) bu farklılığı anlatabilmek için "otomatik biliş" ve "bilinçli biliş" kavramlarını kullanır. Otomatik biliş; örtük, sözle anlatılmayan, hızlı ve otomatiktir. Bu rutin 
günlük biliş, eleştirel olmayan bir şekilde ve büyük ölçüde kültürel olarak mevcut şemaya dayanır (DiMaggio, 1997: 269). Tost (2011: 696) meşruiyet süreçlerinde bu bilişsel özelliği "pasif durum" olarak niteler. Toplumun çoğunluğu bu bilişe göre örgütsel dili anlamlandırır ve hareket eder. Bilinçli biliş ise; otomatik bilişin tersine dışsal, sözlü olarak ifade edilen, yavaş ve bilinçlidir. İnsan motive olduğunda, düşüncesini programlayan biçimleri eleştirel ve tepkisel olarak geçersiz hale getirebilir (DiMaggio, 1997: 271). Tost (2011: 695) bu bilişsel özelliği ise "değerlendirici durum" olarak niteler. Haack vd. de (2014: 638-639) değerlendirici özelliğin yavaş ve bilinçli olduğunu, bilişin otomatik ve hızlı olduğu durumlarda keşfin ve sezginin rolünün ortaya çıktığını belirtir. Bu nedenle otomatik bilişle hüküm elde edenleri değerlendirici değil sezgici kavramı ile tanımlar. Bilinçli bilişin otomatik bilişi geçersizleştirmesi, pratik hayatın içerisinde nadiren olur. Çünkü bilinç otomatik bilişin sunduğu kısayolu reddettiğinde etkisizdir (DiMaggio, 1997: 271). Tost da (2011: 696) pasif durumun yani otomatik bilişin, değerlendirici duruma yani bilinçli bilişe baskın olduğunu ifade eder. Meşruiyet stratejilerinin toplumun çoğunda amaçlanan hükmü oluşturabilmesinin ana sebebi olarak, otomatik bilişin yaygınlığı ve bilinçli bilişin pratikte yaşadığı etkisizlik gösterilebilir.

Zamanla insanlarda otomatik bilişten bilinçli bilişe, bilinçli bilişten otomatik bilişe geçiş yaşanabilir. DiMaggio'ya (1997: 271-272) göre insanlar, bilinçli bilişe üç şart ya da durumda kayar. Birincisi, dikkattir. Insanlar bir probleme karşı dikkat kesildiklerinde kolayca bilinçli bilişe kayar. İkincisi; motivasyondur. İnsanlar özel bir konunun ahlaki boyutu ya da geleneksel açıklamasıyla tatmin olmazsa güçlü bir şekilde motive olur ve kolayca bilinçli bilişe kayar. Üçüncüsü; şema başarısızlığıdır. İnsanlarda var olan mevcut şema, yeni uyarıcılar için yeterli bir şekilde açıklama yapmakta başarısız olduğunda insanlar bilinçli bilişe daha kolay kayar. Pasif durum oluşturan otomatik biliş, meşruiyet hükmünü genelleştirirken, değerlendirici durum oluşturan bilinçli biliş, meşruiyet boyutlarının tamamını göz önünde tutmaya çaba gösterir (Tost, 2011: 702-703). Bilinçli bilişte değerlendirici daha dikkatli, bilinçli ve alışkanlıklarıyla hareket etmeyen bir tutuma sahiptir (Haack vd., 2014: 640). illkinde bilişsel meşruiyet, ikincisinde ise değerlendirici meşruiyetin oluştuğu söylenebilir. Değerlendirici meşruiyet ise ahlaki ve pragmatik olarak ayrılabilir (Golant ve Sillince, 2007: 1149-1150). Örgütsel dilin toplum üzerindeki etkisini araştıranlar açısından, bir probleme dikkat kesilme ve problemin geleneksel yaklaşımla açıklanmasından tatmin olunmaması onları bilinçli bilişe doğru kaydırır. Toplumun etkileşimsel düzende farkına varamadığı sebepleri görmesine ve tespit etmesine yardımcı olur. Örgütsel dili oluşturan meşruiyetin yapıcıları açısından ise, probleme dikkat kesilme ve şema başarısızlığı yöneticilerin bilinçli bilişe kaymalarına neden olur ve örgütsel dilin etkilerini daha iyi değerlendirmelerine katkı sağlar.

\section{Meşruiyetin Yapıcıları}

Modern dönemde aktörün çıkarcı olduğu fakat bu durumun kontrol edilemez bir tutku olmadığı, oldukça rafine bir eylem biçiminde de gerçekleştirilebileceği göz ardı edilmemelidir (Granovetter, 1985: 488). Meyer (2010: 3) modern dönem aktörünün sistemin kuralları içinde meşru fayda ve çıkarına sahip olabileceğini ve doğru faydayı meşru araçlar vasıtasıyla talep edebileceğini ifade eder. Burada meşru çıkar ve yöntem ile meşru gibi görünen arasındaki farkı dikkat çekmek gerekir. Çünkü örgütler meşru olmayan çıkar ve yöntemleri, meşruymuş gibi gösterebilir ya da algılatabilir. Bir şeyin kurumsal olmasa da meşru olabilmesi (Jepperson, 1991: 149) örgütlerin değerlendiricilerin iyi inanç ve güvenini kullanarak, geçerliliği az olmasına rağmen bir şeyi kullanışlı olarak sunabilmelerine imkân tanır (Meyer ve Rowan, 1991: 58). Kurumsal alanın meşrulaşmış biçim ve kavramları kullanılarak manipülatif bir biçimde örgütün liyakati ve kabul 
edilebilirliği gösterilebilir (Elsbach, 1994: 59). Bunu yaparken modern dönem aktörünün iddia edilen özelliklerine uygun bir şekilde, oldukça inceltilmiş rafine ve sofistike yöntemlere başvurulabilir.

Modern dönemde oldukça inceltilmiş olan dil stratejilerinin biçimsel formunu ise genellikle sosyal ve kültürel kurumlar şekillendirir. Powell ve Colyvas (2008: 297) bunu, dilin kullanılma protokolü olarak niteler. Eğer dil formları kurumsal yapıyla uyumsuzluk gösterirse meşruiyet sorununa yol açar (Phillips vd., 2004: 639). Bu nedenle örgütler ancak sosyal ve kültürel yapının biçimlendirdiği dil formları aracılı̆̆ıyla istediği algıyı oluşturabilir. Bu sayede gerçek anlamda değişmek yerine, basitçe beklenti ve sosyal değerlerle uyumlu görünmeyi başarabilir (Asforth ve Gibbs, 1990: 180). Bunun için stratejisini kurumsal normlara uyumlu bir şekilde seçer (Mazza, 1999: 45) ve içinde bulunduğu toplumun kültürünü stratejik bir araç olarak kullanır (Swidler, 1986: 284). Lounsbury ve Glynn (2001: 546) bu süreci kültürel girişimcilik olarak tanımlar.

Kültürün değer sonuçlarına ulaşmak için aktörler tarafından stratejik olarak kullanıldığı tespitine DiMaggio da (1997: 268) katılır. Kültürel unsurların stratejik anlamda kullanılabilme nedeni Swidler'e (1986: 284) göre, onun sosyal hayatta araçsal bir role sahip olmasıdır. Ona göre bireysel ve örgütsel eylemin stratejisini sembolik açıklamalar, efsaneler, törensel bilgi ve toplum ya da örgütün ritüelleri gibi kültürel ürünler belirler. Her ne kadar örgütsel dil stratejisi rasyonellik ve nesnellik açısından eleştiriye uğramışsa da (Phillips ve Oswick, 2012: 451) örgütlerin dili ikna aracı olarak stratejik anlamda kullandıkları kabul edilmektedir (Green ve Li, 2011: 1663). Mesela Glynn ve Abzug (2002: 278) örgütsel isimlerin kurumsal çağrışım yapan alternatifler arasından seçildiğinde, değerlendiriciler tarafından örgütlerin daha meşru algılanmasına katkıda bulunduğunu göstermiştir. Çünkü insani biliş ile dil arasında varsayılan ilişkinin doğası bu değerlendirmeleri destekleyecek özelliklere sahiptir.

Bundan dolayı mikro seviyede bireylerin bilişleri ve diğerleriyle etkileşimlerinin meşruiyet süreçlerinde etkin rol oynadığı güçlü bir şekilde öne sürülebilir (Bitektine ve Haack, 2015: 67). Fakat bu süreçte değerlendiriciler ve yapıcıların bilinçli ya da otomatik bilişe sahip olup olmadıkları ve yapıcılarla değerlendiriciler arasındaki iletişimin niteliği belirleyici olur (Suchman, 1995: 596). Burada yapıcılar olarak başarılı aktörden daha çok diğerleri ile işbirliği yapan sosyal aktörün kastedildiğini belirtmek gerekir (Meyer, 2010: 11). Diğerleriyle işbirliği yapan bu tip sosyal aktör, Habermas'a (2001: 51) göre, nesnel dünyaya yaptığı müdahaleyi iletişimsel eylem üzerinden koordine eder. Zamanla aktörler arasında kurumsal meşruiyet konusunda genel bir ağ oluşabilir (Aldrich ve Fiol, 1994: 654). Bu aktör hem kendisinin hem diğerlerinin hem de değerlendiricinin bilgisini, kimliğini, motivasyonunu ve çıkarını göz önünde tutarak dili kullanır (Green ve Li, 2011: 1671). Diğer türlü tek bir aktörün söylem noktasında birlik oluşturması zayıf bir ihtimaldir (Zucker, 1991: 85). Fligstein'in (1997: 398) kurumsal girişimci olarak tanımladığı bu tip sosyal aktör, iletişim kurabilmesi nedeniyle eylemi gerekçelendirebilme yeteneğine sahip olur ve kurumsal argümanlarla daha uyumlu bir özellik gösterir. Bitektine (2011: 151) de gerekçelendirebilme yeteneğinin meşruiyeti elde etmede önemli olduğunu belirtir. Bu nedenle en önemli özelliği çevresiyle kurduğu ilişki ve ağlar olan modern örgütün, sosyal bir aktör olarak diğerleri ile işbirliği yaptığı, yeni pratiklerin uyumlaştırılmasını sağladığı, çevreye uyum gösterdiği ve oluşturduğu söylemsel anlam sayesinde meşruiyet kazandığı (Meyer, 2008: 791) söylenebilir.

Çevreyle uyum sağlandığına yönelik söylemsel anlamın oluşması ise eylem ile söylem arasındaki tutarlılık görünümüne bağııdır. Modern toplumda bireysel ve örgütsel aktörlerin genelde ikili bir yapı sergilemesi (Meyer ve Jepperson, 2000: 112) tutarlılık görünümü vermesini 
zorlaştırır. Zaten aktörün kimliği ile pratik eylemi arasında var olan bu ayrım sosyolojik düşüncenin en önemli problemlerinden biri olarak değerlendirilmektedir. Bireysel seviyede değerler ve eylem arasında, örgütsel seviyede yapı ve pratikler arasında, ulus devlet seviyesinde ise politikalar ve pratikler arasında ikilik olduğu iddia edilmektedir (Meyer, 2010: 13). Yapı ile pratikler arasında (Scott, 2008: 430) ya da eylem ile söylem arasında (Hasselbladh ve Kallinikos, 2000: 704) ayırımın artması örgütsel meşruiyetin zarar görmesine neden olur (Scott, 1991: 170). Meşruiyet kaygısından dolayı örgütler genelde, yapı ile pratiklerini tamamen örtüştürmek ya da uyumlaştırmak isterler ancak bu oldukça zordur. Kurumsal çevre unsurları ise değerlendirme yaparken örgütün söylem, yapı ve pratikleri arasındaki tutarlılığa dikkat ederler. Örgütler bir yandan bunu bildikleri diğer yandan ise bunu tam anlamıyla başaramayacaklarını ya da bu durumun kendi çıkarları açısından zararlı olduğunu düşündükleri için, yapı ile pratikler arasında tutarlı fakat çoğunlukla sembolik kalan bir uyum görüntüsü vermeye çalışır (Scott, 1991: 172). Bu amaçla değerlendiricilerde uyumlu ve uygun algısı ve hükmü oluşturmak için çeşitli söylem stratejileri geliştirir (Bitektine ve Haack, 2015: 69). Bu stratejiler örgütün meşru kabul edilmesine yardım ederken aynı zamanda örgütün kimliğinin oluşmasına da katkıda bulunur.

Örgütlerle değerlendiriciler arasındaki meşruiyet ilişkisine kategoriler ve kimlik açısından bakan kategoriler yaklaşımı, piyasa kategorilerinin meşrulaşma süreçlerinde söylemsel çerçevenin ve kimliğin önemli olduğunu, meşruiyetin stratejik eylem kadar sembolik eylem tarafından da şekillendirildiğini öne sürer (Navis ve Glynn, 2010: 441-442). Bu bakış açısına göre kategoriler, örgütlerle değerlendiriciler arasında kültürel anlam ve beklentilerle şekillenmiş ortak bir yatırımdır. Aynı kategoride olma, örgütsel aktör ve değerlendiricilere örgütleri değerlendirme ve anlam vermede benzer hassasiyetler kazandırır. Bu da örgütsel kimliğin meşrulaşmasını kolaylaştırır (Glynn ve Navis, 2013: 1132). Creed vd. (2002: 493) söylem stratejilerinin kurumsal mantığın içinde taşıdığı karşıtlıkların yeniden yorumlanmasına neden olduğu için hem örgütün hem de değerlendiricilerin kimliğini yeniden inşa ettiğini öne sürer. Glynn ve Navis'e (2013: 1133) göre bu süreçte oluşan kategoriler ortak kimliğin biçimlenmesini ve korunmasını sağlar.

Sembolik olarak inşa edilen bu kimlik örgütle değerlendiriciler arasındaki sosyal ve kültürel problemleri çözmede kullanılır. Kimliğin yansıması olan örgütsel dilden, tüketici ya da oy vereni bilgilendirmek için ideolojik açıklama yapmada, örgütlerde çalışanlar arasındaki eşitsizliği açıklamak için insan kaynakları departmanına yardımcı olmada, ülke yönetiminde ise insan hakları ve politikalarındaki çeşitli eşitsizlik ve ayrımcılıkları anlatmada yararlanılır (Meyer, 2010: 13). Meşruiyet söyleminin, sosyal aktörler arasındaki güç farklılığı ve eşitsizliğin gerekçelendirilmesinde kullanıldığı görüşüne Boyd da (2000: 343) katılır. Diğer yandan modern aktör dil sayesinde sağladığı bu avantajı gizlemede de yeteneklidir (Granovetter, 1985: 487). Bu amacı düşünmemiş gibi sadece eyleminin meşru ve rasyonel olduğu iddiası üzerine odaklanır (Meyer, 2008: 793). Eylemini rasyonalize ederken sadece söylemsel nedenini belirtmekle yetinir (Green, 2004: 654). Böylelikle bir yandan iyi niyetli algısı oluştururken, diğer yandan da fazla üzerinde durmadığı fakat gerçekte onu asıl motive eden amaçlarını gerçekleştirme imkânı yakalamış olur. Bu nedenle dil, kimliği inşa eden ve yansıtan sosyal bir olgu olarak tanımlanabilirken, diğer yandan da meşruiyetin aracı olarak nitelenebilir.

\section{5. Örgütsel Dil Aracılığıyla Örgütsel Meşruiyetin Üretimi}

Dilin meşruiyet aracı olarak kullanılabildiğini ifade ederken, onun bunu nasıl başarabildiğini göstermek gerekir. Öncelikle meşruiyetin tek taraflı örgütsel bir faaliyetin neticesinde değil, yapıcılarla değerlendiriciler arasındaki karşılıklı etkileşimin sonucu oluştuğu belirtilmelidir (Mas- 
sey, 2001: 155). Örgütsel dil bu etkileşimin temel araçlarından biridir. Değerlendiricilerin yorumlarını biçimlendiren sembollerin kabulünde ve belirli bir niyetle gerçekleştirilen manipülasyonlarda önemli rol oynar (Green vd., 2009: 32). Örgütsel dilin meşruiyet üretimindeki rolüne ilişkin birçok çalışma yapılmıştır. Zimmerman ve Zeitz (2002: 414) yeni örgütlerin hayatta kalmasında söylem yoluyla elde edilen meşruiyetin önemini göstermiştir. Lounsbury ve Glynn (2001: 559) yeni girişimlerin meşruiyet elde etmek için bir girişim hikâyesi inşa etmek zorunda olduklarını söylemektedir. Massey (2001: 168) kriz dönemlerinde tutarlı söylem stratejilerinin, krizin meşruiyete olumsuz etkisini azalttığını öne sürmektedir. Vaara ve Tienari (2008: 991) çok uluslu şirketlerin eylemlerini meşrulaştırmak için söylem stratejileri kullandıklarını belirtmiştir. Pollock ve Rindova (2003: 638-639) araştırmasında, şirketlerin hisselerini halka arz etmek için ön teklif verme süreçlerinde gazete ve dergilerde yer alan makalelerin yatırımcının bilişsel durumunu ve yatırım tercihlerini etkilediği sonucuna ulaşmıştır. Vaara ve Monin (2010: 3-4) şirket birleşmelerinin meşrulaştırılmasında söylem stratejilerinin önemli bir rolü olduğu sonucuna ulaşmıştır. Örgütlerin belirli bir amaca ulaşmada kullandığı bu stratejiler birçok açıdan ele alınabilir. Fakat en yaygın biçimde içerdikleri geçerlilik, uygunluk ve taşıdıkları gerekçeler bakımından değerlendirilmeleri büyük oranda anlaşılabilmelerine yardımcı olacaktır.

\subsection{Geçerlilik}

Bitektine ve Haack'a (2015: 51) göre örgütler, diğerleriyle etkileşime geçerek meşruiyet hükmü elde eder. Meşruiyet bu etkileşim süreçlerinde bireysel seviyede "uygunluk", kolektif seviyede "geçerlilik" şeklinde iki farklı biçimde oluşur. Meşruiyete sosyal ve psikolojik açıdan yaklaşan teori, bakış açısını bu ayrım üzerine odaklar (Johnson vd., 2006: 56). Uygunluk, değerlendiricilerin örgütün pratik ve eylemlerini uygun ve istenilir olarak bulmasıdır. Geçerlilik ise, sosyal bağlamda örgütün faaliyetlerinin uygun olduğuna dair konsensüse referans eder (Bitektine ve Haack, 2015: 51) Geçerlilikte meşru olarak algılanan sosyal düzenin normları, inançları ve değerleri ile diğerlerinin düzeni meşru olarak algıladığı yönünde bir bilincin varlığı önemli rol oynar (Tost, 2011: 686). Uygunlukta ise eylemin sosyal düzenin norm ve kurallarıyla uyumuna ilişkin inancın varlığı etkindir (Johnson vd., 2006: 56). Bu yüzden uygunluk bireysel değerlendiricilerin kendi sosyal kabul edilebilirliğinin hükmüdür. Geçerlilik ise grup, örgüt, örgütsel alan ve toplum gibi daha yüksek seviyede örgütün meşruiyeti hakkındaki konsensüs olarak nitelenebilir (Bitektine ve Haack, 2015: 51).

Mazza da (1999: 11) söylem, konsensüs ve geçerlilik gibi kavramların meşruiyeti açıklamada önemli olduğunu düşünür. Geçerlilikte kabul edilebilirlik bulunması gerekmezken (Habermas, 2001: 53) uygunluk için kabul edilebilirlik zorunludur. Geçerlilik bu yönüyle de uygunluktan ayrılır. Geçerliliğin inşası, bireysel değerlendiricileri etkileyen örgüt, örgütsel alan ve toplum seviyesinde kolektif meşruiyete dayanır (Bitektine ve Haack, 2015: 51). Habermas'ın (2001: 56) sosyal geçerlilik olarak tanımladığı kolektif meşruiyette, bireylerin tek başına örgütsel faaliyetin uygun olmadığını düşünmesi bir anlam ifade etmez. Bir faaliyet bireysel anlamda uygun olmasa bile kolektif anlamda geçerli ve meşru görülebilir (Tost, 2011: 689). Yani bir davranışın ya da yapının meşruiyeti bireysel uygunlukla değil, diğer aktörlerin onları geçerli görmesiyle oluşur (Berger vd., 1998: 380). Diğer yandan meşru örgütler paylaştıkları anlamın kabulü konusunda bireysel anlamda başarısız olabilir (Oliver, 1992: 564) ancak bu sadece uygunluğu ortadan kaldırır. Çünkü bireysel kabul uygunlukla ilgilidir ve örgüt geçerli olduğu sürece meşru olmaya devam eder. Bu nedenle meşru hükümlerle geçerlilik ilişkisi arasında kurulan anlam, değerlendiricilerin günlük olarak uygun gördükleri hükmü çıkarsamada kullanılamaz (Bitektine ve Haack, 2015: 60). 
Kolektif aktörlerin bireysel değerlendiricilerin uygunluk hükümlerine benzer açıklamaları, bireysel uygunluk hükümlerinin hem geçerlilik kazanmasını sağlar hem de uygunluk hükümlerinin doğruluğunu teyit eder (Bitektine ve Haack, 2015: 51). Fakat bu durum kültürel açıklamalar hakkında aktörün kişisel onayı değildir (Johnson vd., 2006: 56). Çünkü bazı bireyler kurumsallaşmış hükümlerde gönüllü olarak anlaşmış olsa bile makro seviye görüş birliğinde mikro seviye bütün bireylerin anlaştıklarını iddia etmek zordur (Bitektine ve Haack, 2015: 60). Aktörler farklı sebeplerden dolayı kurumsal pratiklere uyum gösterebilir ve aynı tutumu sergileyebilir. Sosyopsikolojik yaklaşıma göre bu sebeplerden biri, üst bir otoritenin desteği ya da onayı olabilir (Johnson vd., 2006: 56). Ancak kurumsal hükümler hakkında gösterilen makro seviye konsensüs, sadece bastırılmış uygun hükümleri özel olarak sergilemedeki çeşitliliği değil, aynı zamanda kamusal olarak iletilemeyen bu hükümlerdeki motivasyonun çeşitliliğini de içinde gizli tutar (Bitektine ve Haack, 2015: 60). Bu durum geçerliliğin belirgin olabileceği gibi örtük olabileceğini de gösterir (Habermas, 2001: 53). Bu süreçte bütün meşru hükümler değerlendiriciler tarafından açık bir şekilde ifade edilmez. Olağandışı tercihleri açıklamayı engelleyen çok sayıda faktör vardır. Bunlardan en önemli ikisi, aktif bilişsel süreçlerin engellemesi ve olağandışı hükümlerin kamuya açıklanmasının cesaret istemesidir (Bitektine ve Haack, 2015: 62).

\subsection{Uygunluk}

Bireysel seviyede uygunluk, sosyal bağlamda bir şeyin uyumluluğuna ilişkin bireyin şahsi hükmüne referans eder (Tost, 2011: 689). Bitektine ve Haack'a (2015: 52) göre nasıl makro seviye geçerlilik değerlendiricilerin uygun hükümlerini etkiliyorsa, değerlendiricilerin uygun hükümleri de makro seviye geçerliliğin oluşmasına katkıda bulunur. Bireysel açıdan uygunluk hükümleri durağan değildir ve zamanla pratik hayat içerisinde değişebilir. Bu değişim bireyin içinde gerçekleşir (Habermas, 2001: 53). Bireylerin bu hükümleri açıkça ifade etmesiyle Bitektine ve Haack'a (2015: 53) göre kurumsallaşma ve geçerlilik hükmüne dönüşme süreci başlar. Bu süreçte değerlendiriciler arasında oluşan etkileşimsel ritüel zinciri bireysel hükümleri genelleştirir. Böylelikle meşruiyete dayanak oluşturacak kültürel semboller ve duygusal hassasiyetler var edilir (Collins, 1981: 985). Bitektine ve Haack (2015: 53) uygunluk hükmünün değerlendiricinin söylemi ve eylemi aracılığıyla dışsallaştığında nesnel gerçeklik haline gelerek kurumsallaştığını ve kolektif bir geçerliliğe dönüştüğünü öne sürer. Johnson vd. (2006: 56) de sosyal gerçekliğin kolektif inşasında meşruiyetin bilişsel boyutunun önemli olduğunu düşünür. Fakat Habermas'a (2001: 56 ) göre bu şekildeki çoğulcu uygunluk yaklaşımının mantıksal ve ampirik soyutlamalarını ikna edici bir biçimde uzlaştırmak kolay değildir.

\subsection{Gerekçelendirme (Argümantasyon)}

Örgütsel dil stratejileri ister geçerlilik, ister uygunluk durumunda olsun belirli gerekçeleri içermek zorundadır. Böylelikle yapıya uygun davrandıklarına yönelik bir söylem geliştirebilir ya da faaliyetlerini haklı çıkarabilirler (Scott, 1991: 170). Geçerlilik iddiasının ortaya konduğu sorunsal ve gerekçeden oluşan her bir argüman (Habermas, 2001: 38) meşruiyet amaçlı etkin bir yönetim stratejisi olarak kullanılabilir (Elsbach ve Sutton, 1992: 700). Fakat bunun için tartışmaya açık ve konuşmaya imkân tanıyan bir bağlama ihtiyaç vardır (Green, 2004: 655). Bu şartlar oluşmuşsa örgüt eylemin gerekçesini argümantasyon süreci içerisinde ortaya koyar.

Modern dönemde aktörün, kendinden başka şeyleri de temsil edebilmesinden dolayı, gerekçe üretme imkânı oldukça genişlemiştir. Meyer ve Jepperson'e (2000: 106-108) göre bu aktörün kendini temsil, diğer aktörleri temsil, aktör olmayan varlıkları temsil ve ilkeleri temsil şeklinde dört temsil rolü vardır. Bu modern kültürel yapının belirgin bir şekilde ortaya çıkardığı bir gerçekliktir. Bu kültürel yapının iki kaynağı standardizasyon ve senaryodur. Argümantasyonun 
mantığına uygun olarak aktörler, bir geçerlilik iddiasında bulunurken uyulan ve göreceli olarak sabit olan kurallar gereklidir. İşte standardizasyon ve senaryo bu sabit kuralları ifade eder. Bu kurallar argümanların yapısındaki gömülü kurumlar olarak pratikleri gerekçelendirir (Green, Li ve Nohria, 2009: 11). Searle (2005: 47) bunları "kurucu kurallar" olarak nitelerken, Habermas (2001: 53) bunu "argümantasyonun rasyonelliği" olarak tanımlar. Rasyonellik argüman biçimleriyle ilintili olarak araçsal, değersel, duygusal ve geleneksel olarak sınıflandırılabilir (Etzion ve Ferraro, 2010: 1093). Gerekçeler ise duygusal, akılcı ya da mantıksal, ahlaki ya da değersel şeklinde gruplandırılabilir (Green, 2004: 659). Görülmektedir ki her bir argümantasyon biçiminin içinde kendi rasyonalitesi vardır ve örgütler bu rasyonaliteye uygun gerekçe üretmek zorundadır.

Habermas'a (2001: 38) göre beş argümantasyon sahası vardır. Bunlar hukuk, ahlak, bilim, iş yönetimi ve sanat alanlarıdır. Bilim alanında bilişsel anlatım önermelerin doğruluğunu, sanat alanında değer biçici anlatım değer standartlarına uygunluğu, ahlak ve hukuk alanında ahlaksal ve pratik anlatım eylem normlarına uygunluğu iddia eder. İş yönetimi ya da örgütsel alan ise bütün argümantasyon biçimlerini kullanmak için uygundur. Örgütler duygusal gerekçe ile değerlendiricilerin acıma, affetme, sevme, nefret, haksızlık, pişmanlık, kızgınlık gibi duygularını, akılcı gerekçelerle zekâsının mantıksal yönünü ve bilişsel yapısını, ahlaki gerekçelerle onur, gelenek, adalet gibi ahlaki değer ve etik hassasiyetlerini etkiler (Green, 2004: 659). Modern dönemde aktörün kimliği ile pratikleri arasındaki tutarsızlıklar aktörlerin genişlemesini sağlayarak diğer unsurları daha fazla temsil etmesine imkân tanımıştır (Meyer, 2010: 14). Önemli olan temsil esnasında geçerlilik iddiasını rasyonel gerekçelerle temellendirebilmesidir (Habermas, 2001: 51). Sonuç olarak gerekçeler rasyonalite ve uygunluk üzerine kurulursa, bir eylemin sebep ve doğasıyla bağlantılı olarak meşruluk sağlayacağı söylenebilir (Green, 2004: 655). Bu nedenle gerekçelerin üretildiği kaynak ya da dayandığı temel oldukça önemlidir.

Örgütler ihtiyaç duyduğu rasyonel ve uygun gerekçeleri kültürel ve sosyal çevresinde oluşan (Scott, 1991: 170) ortak görüş, inanç ya da kanıksanmış bilgi, söylem ve pratiklerden geliştirilebilir ya da alabilir (Green, 2004: 655). Çünkü bu özelliklere sahip meşrulaşmış kurumlar çevrelerine hem kural hem de gerekçe sunar (Hybels, 1995: 242). Bu tip gerekçelerden oluşan söylemin içerdiği meşrulaştırıcı bilgi, öznel anlamı dönüştürme yeteneğine sahiptir (Green ve Li, 2011: 1664-1665). Örgütler çevrenin sunduğu kültürel tanımlar ve sosyal yapının desteğiyle işçiler, arkadaşlar, oy verenler adına konuşabilir ve onlar üzerinden eylemini haklı çıkararak meşruiyet elde edebilir (Meyer ve Jepperson, 2000: 107). Burada eyleminin meşru kabul edilmiş bağlama uygun olduğu ve diğerlerinin haklarını savunma konusunda içten olduğu iddiasında bulunabilir (Habermas, 2001: 39-40). İş̧i ve insan haklarından, gelir adaletinden, iş güvenliğinden, çevreyi korumadan, demokrasiden, halk egemenliğinden, yolsuzluklardan bahsederek (Haack vd., 2014: 635-637) içtenliğini ispat etmeye çalışır. Fakat içtenlik temellendirilemez sadece gösterilebilir. Değerlendiriciler ise iddianın içten olup olmadığını ancak söylemle eylem arasındaki tutarsızlıktan anlayabilir (Habermas, 2001: 66). Bu ise örgütün bütün yapı ve pratiklerine hâkim olmayı gerektirir. Gündelik hayatta hem değerlendiricilerin buna imkân ve zamanının olmaması hem de örgütlerin gerçekleri gizleme konusundaki yeteneği varsa içtensizliği fark etmeyi oldukça zorlaştırır.

Değerlendiricilerin örgütlerdeki tutarsızlığı fark edememelerinin diğer bir sebebi ise gerekçelerin ikna edici (Green, 2004: 654) ve saydam olmayan (Habermas, 2001: 53) özellikte üretilebilmesidir. Bazen üzerinde anlamsal uzlaşı sağlanmamış gerekçeler kullanılabilir. Bu amaçla 
örgütsel aktör çevre, ormanlar, hayvanlar, bitkiler ya da farklı canlı türlerinin temsili rolünü üstlenebilir (Meyer ve Jepperson, 2000: 108). Eylem ve politikalarının bu canlı türlerinin faydasına olduğu iddiasında bulunabilir. Dönüşebilir ambalaj kullanımı, egzoz emisyonunun düşüklüğü, düşük enerji sarfiyatı, yeşil fabrika (Waeraas ve Ihlen, 2009: 25), canlı hayvan derisi kullanmama, erozyonla mücadele gibi çevreci söylemlerle (Haack vd., 2014: 634) sosyal değerlere uygun bir anlatımı benimseyebilir. Kamusal algıyı etkilemek için hayvan hakları savunucuları, çevreciler, doğa koruma dernekleri gibi oluşumlarla ortak projeler içinde yer alabilir ya da destek verebilir (David vd., 2013: 360). Bu şekilde eylemleri ile kurumsal alandaki söylem ve baskın kültürün eşleştiğini öne süren bir dil geliştirebilir (Etzion ve Ferraro, 2010: 1093). Fakat bu tip değerler normlar gibi ne genel ne de kişiseldir (Habermas, 2001: 41). Toplumdan topluma kişiden kişiye değişir. Aynı toplum içerisinde farklı değer ölçülerine sahip kişilerin bulunması da oldukça muhtemeldir. Örgütler, hitap ettiği toplumda olabildiğince fazla sayıda değerlendiricinin anlamlı bulduğu değerlere vurgu yapmayı mantıklı görür. Değer standartlarına uygunluk algısı sayesinde örgüt, meşruiyet elde etmede büyük bir avantaj sağlamış olur.

Değerlendiriciyi ikna eden diğer bir neden ise örgütsel aktörün kendini, doğal ve ahlaki hukuk gibi meşrulaşmış çeşitli ilkelerin temsilcisi olarak gösterebilmesidir (Meyer ve Jepperson, 2000: 108). Ahlaki vurgu sosyal ve kolektif ilgileri uyandırma (Green, 2004: 660) yoluyla, hukuk kurallarına uygunluk ise doğrudan meşrulaştırıcı etki ortaya çıkarabilir (Stryker, 1994: 848). Örgüt bu sayede evrensel bir değerlendirici kitlesine hitap ederek genel onaya ulaşabilir (Habermas, 2001: 51). Bunun için adalet, eşitlik, özgürlük, insan hakları gibi kavramların gözetildiği ve savunulduğu şeklinde bir argüman kullanabilir (Haack vd., 2014: 637). Burada argümanların mantıksal çıkarım anlamında zorlayıcı olmaması ve açık bir şekilde bağlantısının kurulabilmesi gerekir (Habermas, 2001: 38). Bu sayede örgüt meşru ilkelere uygunluğunu gösterebilirse değerlendirici kitlesini ikna edebilir ve amaçladığı meşruiyet hükmünü elde edebilir.

Örgütler diğer yandan evrensel onayı alabilmek için hemen hemen bütün toplumlarda itibar gören bilimin de temsilciliğini üstlenebilir. Çünkü bilimsel ve teknik uzmanlığın meşrulaşmaya yardım ettiği düşünülür (Stryker, 1994: 849). Bu nedenle yapı ve faaliyetlerinin bilimsel açıdan evrensel doğrulara uygun olduğu iddiasında bulunur. İddiasını desteklemek için istatiksel veri ve analizleri kullanabilir (Harmon vd., 2015: 79). Modern dönemde uzmanlık bilgisi ya da bilimsel bilginin doğası formel, tarafsız ve nesnel olmaktan çok mit ve sembollerden oluştuğu (Green ve Li, 2011: 1664) ve bilimin otoritesi bütün soruların cevabında yol gösterici olarak benimsendiği için bilim aracılığıyla değerlendiricileri ikna etmek ve meşruiyete ulaşmak mümkün görünmektedir (Meyer, 2010: 8). Ürünlerin tanınmış labaratuvarlarda onaylatıldığı, uzman hekimlerin tavsiye ettiği, dünyaca kabul edilen kuruluşların sertifikalandırdığı, üniversiteler ile işbirliği halinde hazırlandığı, bilimsel çalışmalara uygun olduğu, istatistiksel verilerle doğrulandığı şeklindeki anlatımlar, örgütlerin meşruiyet elde etmeleri için kullanılmakta ve bu sayede değerlendiricide geçerli ve uygun hükmü oluşturulabilmektedir. Bilimin bu amaçla yaygın bir şekilde kullanılması göstermektedir ki bilimsel değerin öneminin yaygınlaşması kendi ilgi alanının dışında gerçekleşmektedir. Bilim etkinliğinin yaygınlaşmasında ise işlev ve gerekliliklerinin çok az ilgisi olduğu görülmektedir. Bu nedenle bilime dair efsaneler ve meşrulaştırıcı etkinin en az işlevi kadar yaygınlaşmasında rolü olduğu söylenebilir.

Yukarıda gerekçelendirme ile ilgili anlatılanlardan da anlaşılacağı üzere argümantasyonda önemli olan değerlendirici aktör için neyin geçerli olduğudur (Habermas, 2001: 53 ). Burada değerlendirici gerekçeye kişisel olarak inanmasa dahi eğer kabul ettiyse uygundur ve diğerlerine 
de ona uygun olduğu için inanır (Zelditch, 2001: 7). Gerekçelendirmeyi güçlü kılan yapı ve düzenden daha fazla bir şeydir (Habermas, 2001: 56). Estetik değerler, toplumsal normlar, ahlaki kurallar, bilimsel doğrular, sembolik anlamlar ve içtenlik gibi pek çok unsur gerekçelendirmeyi etkin yapan temel faktörlerin başında gelir. Bir gerekçede bunların biri, tamamı ya da bir kısmı birlikte bulunabilir (Green, 2004: 659). Değerlendiriciler bunlara bireysel olarak inanmasa bile uygun gördükleri takdirde geçerli olur (Zelditch, 2001: 6). Eğer bu unsurlar arasında tartışmalı bir durum varsa ortak geçerli olanın yardımıyla ortak geçerli olana dönüştürülebilir (Habermas, 2001: 38). Patriotta vd. (2011: 1806) Avrupa'da nükleer enerji karşıtlığına rağmen nükleer yatırımların gerekçelendirme yoluyla nasıl meşru hale getirildiğini göstermiştir. Boyd (2000: 348) sigara, petrol ve nükleer alanda faaliyet gösteren şirketlerin insana ve doğaya verdikleri zararlar konusunda gerekçe içeren söylemlere başvurduğundan bahseder. Vaara ve Tienari (2011: 371) çok uluslu şirketlerde birbiriyle çelişen küreselleşme ve milli çıkar baskısının söz konusu olduğunu belirtir. Bu tip durumlarda ortak geçerli olan gerekçelerin kullanıldığı söylenebilir (Green, 2004: 658). Böylelikle geçerlilik ve uygunluk amacıyla duruma uygun gerekçelerden oluşturulan örgütsel dil, döngüsel bir şekilde örgütsel hayat sürecinde sürekli olarak yeniden üretilir.

\section{6. Örgütsel Dilin Oluşturulması ya da Söylem Üretimi}

Örgütsel analizde her bir yaklaşımın iletişim ve söyleme bakışı birbirinden farklıdır. Kurumsalcı geleneğin örgütsel iletişim stratejilerine tek başına ayrı bir yer vermemeye özen göstermesinden dolayı, kurumsalcılar arasında iletişimsel eylemin meşruiyetin elde edilmesindeki rolü hala tartışmalıdır (Elsbach, 1994: 59; Cornelissen vd., 2015: 11). Bu nedenle örgütleri pasif varlıklar olarak varsaymakla eleştirilir. Pratik hayatta örgütlerin amaçlarına ulaşmak için çeşitli söylem stratejileri geliştirebilmesinden dolayı Oliver (1991: 173-174), Lounsbury ve Glynn (2001: 559) gibi araştırmacılar kurumsalcı teori ile kaynak bağımlılı̆ı yaklaşımını birleştirerek bu boşluğu kapatmak ister. Oysaki bu çalışmada söylem stratejilerinin kurumsal kuram içerisinde değerlendirilebileceği iddia edilmektedir. Örgütlerin sembolik unsurları kullanarak somut eylem ve yapılarını değiştirme ihtiyacından kurtulabileceği (Suchman, 1995: 588) ve böylelikle daha esnek ve kaynakları koruyan bir yöntemle amaçlarına ulaşabileceği öne sürülmektedir(Asforth ve Gibbs, 1990: 182). Bu süreçte değerlendiricilerin örgütlerin lehine sosyal bir hükümde bulunmaları için kültürel unsurların ve sembollerin etkin bir şekilde kullanılabileceği vurgulanmaktadır (Suchman, 1995: 588). Harmon vd. (2015: 77) söylemin yapısını anlamanın sosyal aktörler arasındaki ilişkiyi açıklamaktan daha çok, meşruiyeti analiz etmeye katkıda bulunacağını düşünür. Bu nedenle çalışmanın bu kısmı, söylemin yapısını anlamaya çalışarak meşruiyeti daha anlaşılır bir şekilde açıklamaya odaklanmıştır.

Örgütsel analizde söylem kavramına genel anlamda iki tür yaklaşım vardır. İlki söylemi bir eylem olarak gören yaklaşım, diğeri ise söylemi inşa edici olarak gören yaklaşımdır. İlkinde sadece söylemi gerçekleştiren aktör varken, ikincisinde birbirleriyle etkileşim halinde söyleyen ile değerlendiren aktörün varlığı söz konusudur (Harmon vd., 2015: 77) ve iletişimin sosyal boyutu dikkate alınır (Green vd., 2009: 13). İlk yaklaşımda söylem iletişim eylemi seviyesinde ele alınırken, ikincisinde söylemin derindeki yapısal seviyesine odaklanılır. Illetişim seviyesi stratejik ifadeyi, yapısal seviye ifadenin yapısal kurallarını tanımlar (Golant ve Sillince, 2007: 1151). Söylemin yapısal boyutu, aktörün yorumlayıcı şeması ile ilgilidir (Heracleous ve Barret, 2001: 755758). Bu iki özelliği sayesinde söylem hem gerçekliğin sosyal inşasında rol oynar hem de örgütler hakkında değerlendiricilere bilgi aktarımında kullanılır (Grant vd., 2001: 8). Green ve Li (2011: 1671) ilk yaklaşımı klasik, ikincisini ise çağdaş olarak niteler. Ona göre klasik söylem yaklaşımı, 
insanların kelimeleri nasıl kullandığı üzerine, çağdaş yaklaşım ise kelimelerin insanları nasıl kullandığı üzerine odaklanır.

Söylemsel eylem yaklaşımı söylemi, sosyal pratik ve eylem olarak görür ve iletişim seviyesinde sosyal etkileşimin temeli olarak kabul eder. Bağlama dikkat etmeksizin etkileşimde mikro seviyeyi ele alır (Heracleous ve Marshak, 2004: 1-2). Bu seviyede aktör yorumlayıcı şeması ile elde ettiği kendi öznel anlamını diğerlerine söylem aracılığı ile aktarır (Green ve Li, 2011: 1664). Öznel anlam bilinç ya da bilinçaltında oluşabilir. Pratik bilinç aktörün eylem ve sosyal şartlar hakkında bir bilgi ya da inanca sahip olması fakat bunu açıkça ifade edememesi durumuna işaret eder (Heracleous ve Barret, 2001: 758). Örgütler çevresindekilere bilgi verme sorumluluğundan dolayı (Woodward vd., 1996: 333) söylemi araçsal olarak amaçlarına hizmet etmekte kullanır (Elsbach, 1994: 60). Bu anlamda söylem meşruiyetin yapıcısı olan örgüt ile değerlendiricisi arasında bir nevi kanal işlevi görür. Burada meşruiyetin yapıcısı mesajı gönderen, değerlendiricisi ise mesajı çözen ve anlayandır (Cornelissen vd., 2015: 12). Örgüt açısından önemli olan değerlendiriciye mesajı iletilebilmek ve değerlendirici tarafından istenen şekilde anlaşılabilmektir (Hasselbladh ve Kallinikos, 2000: 710). Bu iletişim sürecindeki söylemin niteliği meşruiyetin belirleyicisi olur (Suchman, 1995: 586). Bu anlamda meşruiyet çevreye iletilen mesajlar üzerine kurulmuştur denebilir (Boyd, 2000: 345). Bansal ve Clelland (2004: 100) şirketlerin hisse senedi fiyatları ile meşruiyet algıları arasındaki ilişkiye yönelik araştırmasında, yatırımcının şirkete ilişkin bilgisinin o şirketin meşruiyetine ilişkin hükmüne etki ettiği bulgusuna ulaşmıştır.

İnşacı yaklaşım ise söylemi, sembolik eylem olarak kabul eder ve gerçekliğin sosyal olarak inşa edildiğini düşünür (Heracleous ve Marshak, 2004: 1-2). Bu yaklaşıma göre dil sadece ne gördüğümüzü değil, aynı zamanda düşüncelerimizi inşa etmek için kullandığımız mantı̆̆ımızı da etkiler (Brown ve Humphreys, 2006: 233). Bu nedenle kurumsal mantığa sahip olan örgütlerin sembollerden oluşan bilgisel yapılar (Green ve Li, 2011: 1665) olarak tamamen söylemden oluştuğunu varsayar (Boje vd., 2004: 571). Bu bakış açısına göre söylem ile kurumlar arasında bir etkileşim vardır (Phillips vd., 2004: 646). Cornelissen vd. (2015: 14-15) geliştirdikleri “iletişimsel kurumsalcılık" yaklaşımında, kurumların iletişim açıklamalarıyla oluştuğunu, korunduğunu ve değiştiğini savunur. Harmon vd.'ne (2015: 76) göre ise, iletişimin kurumlarla nasıl bir ilişki içinde olduğunu anlamamı için iletişim stratejileri ile değerlendiricinin meşruiyet algısı arasındaki ilişkiyi açıklamak gerekir.

Söylemi derin yapı seviyesinde ele alan bu yaklaşımın dayanağı Giddens'ın (1984: 15) yapı teorisinin temelini oluşturan kurallar ve kaynaklardır. Derin yapı göreceli olarak durağan, içsel ve sürekli olarak tekrar eden bir özelliğe sahiptir. Bu yapılar bireysel metin, konuşmacı, yazar, bağlam ve iletişim eylemini etkileyen uzun dönemde oluşmuş, söylemin sürekli ve değişime dirençli özelliklerini ifade eder. Bunlar söyleme biçimini veren kurallardır. Söylemin yapısal özelliklerini oluşturan bu kurallar merkezi temaları, genelleşmiş metaforları ve retorik stratejilerini içerir (Heracleous ve Barret, 2001: 758). Bu kurallar genelde örtülüdür ve söylemdeki gömülü anlamı ifade eder. Sosyal etkileşimde kelimelere tamamen dönüşemediği için sözsüz bir özellik taşır (Collins, 1981: 990). Gömülü anlam, etkileşimin beklenen rolünün dışında gizli, örtük ve niyetli bir amaca hizmet eder (Granovetter, 1985: 490). Bu açıdan bakılırsa meşruiyet söylemlerinde, gömülü olarak karşıtlık ya da destek ifade eden mesajlar hissedilebilir (Creed vd., 2002: 493). Dilsel eyleme yön veren bu kurallar insanlar tarafından nadiren fark edilir ve bilinir. Örtük anlamın daha derin seviyelerinde bu durum daha da geçerlidir (Collins, 1981: 991). Bu nedenle söylem stratejilerinin, sosyal aktörün hem meşruiyet algısını yansıttığı hem de onu şekillendirdiği söylenebilir (Harmon vd., 2015: 76). 
Söyleme farklı bir yönden yaklaşan eleştirel söylem analizi ise söylemi, işlev ve sonuçlar üzerinden değerlendirir. Bu yaklaşıma göre söylem üretim, dağıtım ve metinlerin okunmasında kontrol imkânı sağlayan güçtür ve üç ana boyutu vardır. Birincisi metin boyutudur. Bir yazılı metin altında metnin anlamı, yapı ve içerik deneyimlenir. İkincisi söylem pratiği boyutudur. Etkileşimde söylem formu, iletişimin alışıldık anlamı ve inançları deneyimlenir. Üçüncüsü sosyal pratik boyutudur. Söylemin gerçekleştiği ortamdaki sosyal bağlamın göz önünde tutulmasıdır (Grant vd., 2001: 7). Bu üç boyut nedeniyle söylem ve kelimeler aktör üzerinde baskı kurabilecek ve etki üretebilecek güce ulaşır (Cornelissen vd., 2015: 13). Bu yaklaşım gücü, modern toplum ve örgütlerde kontrolün nasıl sağlandığını anlamada merkezi bir kavram olarak görür. Söylemi ise örgütlerin yeni anlam üretimine hizmet eden meşru formlar olarak tanımlar (Oakes vd., 1998: 258). Örgütlerin söylem aracılığıyla elde ettiği anlamların kendisine diğerleri üzerinde bir kontrol gücü oluşturduğunu iddia eder.

Söylemin içeriği ve kapsamına göre de iki yaklaşım vardır. Söylem kavramını geleneksel ve dar bakış, yazılı metni dışarıda tutarak sadece konuşma formu olarak tanımlar. Son zamanlarda yaygın olan geniş bakış ise, hem yazılı metin hem de konuşma formunun birleşimi olarak görür. Bu yaklaşıma göre söylem, bütün yazılı metin çeşitleri ile formel ve informel etkileşim süreçlerindeki konuşma formlarının tamamını içerir (Grant vd., 2001: 7). Bu yaklaşımda metinlerin üretimi, yayılması ve tüketimi süreçlerini de kapsayan bütün yazma ve konuşma pratikleri söylemin içine dâhil edilir. Bir nevi söylem, pratikte üretilen maddi gerçekliğin somutlaşmış hali olarak kabul edilmektedir (Hardy, 2001: 26). Bu bakış açısında söylem belki basitçe metinlerin anlamlarının toplamı olarak görülebilir fakat kesinlikle bir metnin transkripsiyonu değildir. İçerisinde sembolik ifadeler barındırır. Bu anlamda çeşitli formlar, yazılı dokümanlar, sözlü raporlar, sanat eserleri, sözlü beyanatlar, resimler, semboller, binalar ve birçok üretilmiş olan şey içerisinde üreticilerinin bilinçli ya da bilinçsiz mesajını içerdiği için söylem olarak kabul edilebilir (Phillips vd., 2004: 636).

Bu çalışmada kullanılan örgütsel dil kavramı, söylemi geniş anlamda tanımlayan yaklaşıma oldukça yakındır. Bu yüzden "örgütsel dil” ve geniş anlamıyla "örgütsel söylem" kavramları birbirlerinin yerine kullanılabilir. Buradaki örgütsel dil ifadesi karşılıklı konuşma, günlük konuşma ya da söylemin oldukça ötesinde, açıklama yöntemi ve düşünce setleriyle ilgili bir kavram olarak düşünülmelidir. Bu yaklaşımda hem söylem hem metin hem de bağlam önemlidir (Phillips ve Oswick, 2012: 442). Örgütün açıklama yapma, algı oluşturma, bilgilendirme, manipülasyon yapma gibi eylemlerinde kullandığı bütün araçlar örgütsel dilin içine dahil edilebilir. Bu haliyle konuşma, metafor, retorik, metin, anlatı ve hikaye gibi dilsel unsurları kapsadığı gibi (Heracleous ve Marshak, 2004: 1) ses tonu, beden dili, diyalog, konuşma tavrı gibi davranışları (Cornelissen vd., 2015: 11) ritüel, drama gibi sembolik eylemleri ve müzik, sanat, mimari gibi kültürel eserleri de içerir (Grant vd., 2001: 7-8).

Söylem stratejileri ya da tipleri üzerinde çeşitli sınıflandırmalar olsa da, bunların benzer yönleri oldukça fazladır. Lawrence ve Phillips (2004: 695-702) meşrulaştırıcı etkisi olan düzenleyici, çevreci ve popüler kültür olmak üzere üç makro kültürel söylem tipi tanımlar. Suddaby ve Greenwood (2005: 45) varoluşsal (ontological), amaçsal (teleological), evren bilimsel (cosmological), tarihsel (historical) ve değersel (value-based) olmak üzere beş retorik stratejisi olduğunu ifade eder. Leeuwen ve Wodak (1999: 104-110) otoriteleştirme, rasyonelleştirme, ahlakileştirme ve hikayeleştirme şeklinde dört söylem stratejisi belirler. Vaara vd. (2006: 790) bunu geliştirir ve normalleştirme stratejisini de ekleyerek beşe çıkarır (Vaara ve Tienari, 2008: 988). Normalleştirme; yaygın olana, otoriteleştirme; geleneğin, örfün, hukukun ve kurumsal otorite 
düzeyinde olan insanların otoritesine, rasyonelleştirme; bilişsel geçerliliğe hitap eden bilgi ve sebep unsurlarına, ahlakileştirme; değerler sistemine atıf yapmaya referans eder. Hikayeleştirme ise örgütün tarihine gönderme yapmayı ve ondan esinlenmeyi ifade eder (Vaara vd., 2006: 794). Araştırmacıların sınıflandırdığı bu söylem stratejileri birbirine oldukça benzemekle birlikte oldukça da kullanışlıdır. Fakat bireysel ve kolektif aktörlerin meşruiyet algıları ve hükümleri geçerlilik ve uygunluk şeklinde tanımlandığı için söylem stratejilerinin de bu açıdan ayrı ele alınmasında fayda vardır.

Bitektine ve Haack'a (2015: 64-65) göre stratejiler her iki değerlendirici tipi üzerine farklı olmalıdır. Geçerlilik üzerine söylem stratejileri; uygunluğa vurgu yapan stratejiler, otoriteye vurgu yapan stratejiler, doğal bir varlık ya da gelişmeyi vurgulayan stratejiler, favori kategorileri öven stratejiler, tarihsel hikâye ya da anlatılar üzerine kurulu stratejiler, metaforlar üzerine kurulu stratejiler olarak sıralanabilir. Uygunluk üzerine söylem stratejileri ise; bir varlığın başarısını vurgulayan stratejiler, değerlendiricinin normatif inançlarını yansıtan stratejiler, bir varlığın kimliğini inşa eden stratejiler, varlığın ahlaki değerlerine vurgu yapan stratejiler, duyguları yönlendiren stratejiler olarak ifade edilebilir. Bu sınıflandırmanın Habermas'ın (2001: 38) gerekçelendirme biçimleri konusundaki sınıflandırmasına büyük ölçüde benzer olduğu söylenebilir. Diğer yandan Harmon vd.'nin (2015: 77) hem içsel seviye ve kolektif seviye ayrımına hem de söylemin yapısal unsurları olarak gösterdiği bilgi, teminat, iddia ve destek kavramlarına uygun olduğu öne sürülebilir. Ayrıca Etzion ve Ferraro'nun (2010: 1093) meşruiyet stratejilerinde mantığa, etik ilkelere, duygulara ve motivasyona hitap eden kelimeler kullanıldığı yönündeki tespitlerini de kapsayan bir sınıflandırma olur. Bu nedenle örgütlerin söylem stratejilerini açıklarken bu sınıflandırmayı temel almak faydalı olacaktır.

\subsection{Geçerlilik Üzerine Söylem Stratejileri}

Uygunluğa vurgu yapan stratejiler: Bu tür stratejiler örgütsel yapı ve pratiklerin örgütsel alanda kabul edilmiş ve kanıksanmış olan yaygın yönetim tekniklerine, ilan edilmiş kurallara, ilkelere ve pratiklere uygun olduğuna yönelik geliştirilen söylemleri içerir (Bitektine ve Haack, 2015: 64). Özellikle teknoloji, piyasa ve yönetimi anlamak için uzmanlık gerektiren konularda mesleki mantık ve kelimelerin kullanımı yaygındır (Sillince, 2005: 613). Örgütler faaliyet, ürün ya da yöntemlerinin dünya genelinde kabul gören ve uygulananlarla benzer olduğunu vurgulayabilir (Suchman, 1995: 598). Müşteri memnuniyetinin önemsendiğini göstermek için müşteri hizmetleri departmanının, etik ilkelere uyulduğunu göstermek için etik komitesinin, iş güvenliğine önem verildiğini göstermek için iş güvenliği ve sağlığı biriminin kurulduğunu açıklayabilir (Asforth ve Gibbs, 1990: 181). Bütün süreçlerde müşteri beklentilerinin öncelikli olduğunu göstermek için toplam kalite yönetimi anlayışının benimsendiğini ilan edebilir (Zbaracki, 1998: 629630).

Oysaki bu uygulamalar içeriğinden çok sembolik anlam taşır. Westphal vd. (1997: 388-389) toplam kalite yönetiminin törensel uygulamaları ile örgütsel meşruiyet arasındaki ilişkiye dikkat çekmiştir. Zbaracki (1998: 630-631) toplam kalite uygulamalarındaki gerçeklik ile söylem arasındaki farklılığa işaret etmiştir. Zimmerman ve Zeitz (2002: 426) örgütlerin değerlendiricileri etkilemek için kullandıkları yeni teknolojinin potansiyelini övdüklerini ve uygulamalarının endüstrinin eğitim standartları ile uyumlu olduğuna ilişkin söylemde bulunduklarını belirtir. Bu stratejilerle yapılmaya çalışılan çıktı, hedef ve yöntemlerin değerlendiricilerin beklentileriyle uyumlu olduğunun gösterilmesidir (Dowling ve Pfefer, 1975: 127). Fakat buradaki değişim ve uygulama yapısal değil semboliktir (Suchman, 1995: 598). Uygulamalar ya söylem boyutunda kalır ya da en fazla törensel olarak hayata geçirilir. 
Otoriteye vurgu yapan stratejiler: Bu tür stratejiler hukuka, mesleki düzenlemelere, uzmanlık gücüne ve güçlü aktörlere atıf yapar (Bitektine ve Haack, 2015: 64). Örgütler eylem ve yapılarının, otoriteyi temsil eden kolektif düzenleyicilerin yasa ve diğer formlarıyla uyumlu olduğunu iddia edebilir (Tost, 2011: 693). Komisyonlar, aracı kuruluşlar ve mahkemeler gibi kolektif otoritelerin karar ve görüşlerini meşrulaştırıcı olarak kullanabilir (Stryker, 1994: 850). Yine meslek uzmanları, bilim insanları ve meslek profesyonellerini faaliyetin, yöntemin ve çıktının değeri ve kalitesi konusunda garantör olarak gösterebilir (Jepperson ve Meyer, 1991: 206). Örgütsel performansı desteklemek (Golant ve Sillince, 2007: 1153) veya faaliyetlerinin hesabını vermek için (Meyer ve Jepperson, 2000: 103) bilimsel veri ve bilgiyi kullanabilir. Danışmanlık firmalarının strateji ve operasyon konusundaki tavsiyelerini kaynak gösterebilir (David vd., 2013: 357). Ayrıca tescil, lisans ve sertifika kuruluşlarını ürünlerinin sosyal destek görmesinde onaylatıcı olarak kullanabilir (Bitektine, 2011: 156).

Uzmanlık otoritesi meşruiyete, bilginin kendisinden çok daha önemli katkı yapabilir (Green ve Li, 2011: 1664). Bu nedenle otorite konumunda bulunan danışman, uzman ve düzenleyici kuruluşlar, bir örgütte verimliliğin ve kalitenin geliştirildiğini haklı çıkaramasalar bile meşruiyetin kazanılmasında önemli rol oynayabilir (Meyer ve Rowan, 1991: 56). Ayrıca uluslarüstü küresel kuruluşların örgütsel formları, meşruiyeti elde etmede oldukça başarılıdır. Onların meşruiyeti küresel ölçekteki destekle sağlanır (Haack vd., 2014: 635). Örgüt bu kuruluşlara atıf yapabilir. Uygulamalarının tüketici hakları derneğinin tarafsız ve bilimsel kararlarıyla doğrulandığı söyleminde bulunabilir (David vd., 2013: 359). Diğer yandan meşruiyet sürecinde medya, düzenleyici kuruluşlar (Deephouse, 1996: 1024), yasal sistem (Bitektine ve Haack, 2015: 67), politikacllar ve akademisyenler gibi farklı otoriteler önemli rol oynar (Haack vd., 2014: 635). Yine aynı şekilde seçkin ve popüler kişilerin desteği önemlidir (Suchman, 1995: 596). Kültür, eğlence, müzik, spor, iş dünyası ve politikadaki tanınmış kişiler örgütün fark edilirliğini artırır (Navis ve Glynn, 2010: 444) ve dikkat çekmesini sağlar (Glynn ve Abzug, 2002: 268). Örgütler tanınmış kişileri yönetim kurullarına üye yaparak ve ürünlerinin ünlüler tarafından kullanıldığını veya onaylandığını açıklayarak toplumsal desteği artırabilir (Asforth ve Gibbs, 1990: 181).

Doğal bir varlık ya da gelişmeyi vurgulayan stratejiler: Bu stratejiler küreselleşme (Vaara ve Tienari, 2011: 381) ve modernizm (Golant ve Sillince, 2007: 1152) gibi siyasal gelişmelere, iklim değişikliği (Waeraas ve Ihlen, 2009: 27-28) gibi doğaya ilişkin gelişmelere, teknik ilerlemeler gibi teknolojik gelişmelere (Kraatz ve Zajac, 1996: 832), moda akımları gibi kültürel gelişmelere atıf yapar (Zimmerman ve Zeitz, 2002: 426). Bu stratejilerde amaçsal bir gerekçelendirme söz konusudur (Bitektine ve Haack, 2015: 64). İkna edici argümanlar nedenler üzerine kurulur ve doğal süreçlere vurgu yapılır (Suddaby ve Greenwood, 2005: 54-55). Vaara ve Tienari (2011: 381) şirket birleşmelerinin meşruiyetinde küreselleşme argümanının önemli olduğunu belirtir. Waeraas ve Ihlen (2009: 27-28) teknoloji, otomotiv ve tüketim firmalarında çevreci söylemlerin meşruiyete katkısını göstermiştir. Strang ve Bradburn (2001: 129) neoliberal söylemin sağlığı koruma örgütlerinin politikalarını meşrulaştırmada kullanıldığını ifade eder. Kraatz ve Zajac (1996: 831) teknik gereklilikler gerekçe gösterilerek kurumsal açıdan uygun olmayan faaliyet ve yapıların meşrulaştırabileceğinden bahseder.

Favori kategorileri öven stratejiler: Bu tür stratejiler örgütlerin varlıksal olarak başka bir varlıkla karşıtıı taşıyıp taşımadığı veya birlikte var olup olamayacağı mantığı üzerine kuruludur (Suddaby ve Greenwood, 2005: 51). Düşmanlardan bahsederek kendisini iyiler kategorisi içerisinde gösterebilir ve değerlendiricilerin kaygıları üzerinden bir algı oluşturabilir (Brown, 1997: 653). Diğer taraftan bireysel olarak üye olduğu kategorilerdeki pozisyonunu güçlendirmeye ve 
onlardan meşruiyet açısından faydalanmaya çalışabilir (Bitektine ve Haack, 2015: 64). Üyesi olduğu kuruluşlardan, hisselerinin satıldığı borsalardan ya da sıralamaya girdiği dünyaca ünlü listelerden bahsedebilir.

Tarihsel hikâye ya da anlatılar üzerine kurulu stratejiler: Bu stratejiler mitsel ve tarihsel hikâyeler, gelenekler (Suddaby ve Greenwood, 2005: 52), adetler gibi kültürel unsurlar üzerine kuruludur (Bitektine ve Haack, 2015: 64) ve bu anlamda yöneticilerin uzmanlığı hikaye anlatmaya uygun sosyal yetenek ve mitlerle dolu manipülatif anlatılar üretmektir (Green ve Li, 2011: 1664). Örgütlerin faaliyetleri konusunda nesnel anlamda geçerli argümanları bulunmuyorsa hikâye anlatımı gibi alternatif iletişim formlarından yararlanılır (Aldrich ve Fiol, 1994: 652). Ritüeller, mitler ve folklorik kültür öğelerine vurgu yapılır (Asforth ve Gibbs, 1990: 186). Değerli görülen tarihsel olaylar üzerine kurulu söylemler aracılığıyla stratejik bir hikâye geliştirilir (David vd., 2013: 357). Bu hikâyeler sembolik alanda bir söylem ortaya çıkardığı için bir düzen ve nesnellik oluşturma potansiyeline sahiptir (Lounsbury ve Glynn, 2001: 549).

Ayrıca hikâyeci söylem formunun araçsal ve temel bir rolü vardır (Golant ve Sillince, 2007: 1152). Bu anlatı ve hikâyeler, söylemin içeriğinden çok pratik ve yapının tasvirini sağlar ve sosyal önemini kıymetlendirmeye yarar (Hasselbladh ve Kallinikos, 2000: 706). Mesela yeni yatırımlarla ilgili yaratılan hikâyeler örgütsel çevrede potansiyel fırsatların dikkat çekmesini sağlar (Lounsbury ve Glynn, 2001: 549). Gelenekler ise kolektif eylem ve koordinasyon problemini çözmede kullanışlıdır (Etzion ve Ferraro, 2010: 1093). Vaara ve Tienari (2011: 387) İskadinav ülkelerinin şirketleri arasında birleşme ve satınalma faaliyetlerinin küreselci, ulusalcı ve bölgeselci temelde meşruiyetini sağlamak için kullanılan anlatı stratejisinin etkili olduğunu söyler. Bu nedenle anlatı ve hikâyeler kamusal alanda geçerli iletişim formuna dönüştürülür (Aldrich ve Fiol, 1994: 652) ve maksatlı bir şekilde anlamı değiştirmek ya da yönetmek için kullanılır (Vaara ve Tienari, 2011: 370).

Metaforlar üzerine kurulu stratejiler: Bu stratejiler analojiler ve benzetmeler gibi söylem yöntemleri üzerine kuruludur ve bu stratejilerde genelde benzer kaynaklara dayanan fakat bilinmeyen varlıklar meşruiyet sebebi olarak gösterilir (Bitektine ve Haack, 2015: 64). Çünkü metaforlar benzer olmayan alanların öz kavramlarının algısal olarak kullanımını ifade eder. Böylelikle aslında olmayan ya da olduğundan daha az bir şeyi daha görünür ve gerçek kılabilir (Navis ve Glynn, 2010: 443). Bu nedenle metaforlar konuşma biçimleri olarak sadece retorik seviyesinde değil insani bilişin de önemli bir unsuru olarak değerlendirilir (Etzion ve Ferraro, 2010: 1094). Meşruiyetin doğası bilişsel olduğu için örgütsel problemin fark edilmesi olumsuz etki yapabilir (Suchman, 1995: 595). Analoji ve metaforlar kurumları derinlemesine değerlendirmeye izin vermeyerek analitik kapanmaya yol açar ve böylece politik destek ve meşruiyete yardım eder (Etzion ve Ferraro, 2010: 1092). Bu nedenle örgütler hikâye, anlatı ve kültürel vurguları olan analoji ve metaforlarla değerlendiricilerde olumlu çağrışım sağlayabilir ve olumlu hüküm oluşturmaya çalışabilir (Mazza, 1999: 10). Bundan dolayı analojilerin normatif ve bilişsel meşruiyetin oluşmasına önemli katkılar yaptığı öne sürülebilir (Etzion ve Ferraro, 2010: 1093).

\subsection{Uygunluk Üzerine Söylem Stratejileri}

Varlığın başarısını vurgulayan stratejiler: Bu stratejiler başarı ya da başarısızık hikayeleri, problem ve çözüm söylemleri, rasyonelleştirme gibi unsurlar üzerine kuruludur (Bitektine ve Haack, 2015: 65). Başarı durumunda öncelikli olarak böyle bir sonucun gerçekleşmesinin ne kadar önemli olduğundan bahsedilebilir (Hasselbladh ve Kallinikos, 2000: 704), örgütün temel yetenekleri öne çıkarılabilir (Golant ve Sillince, 2007: 1153) ya da sonuçları abartılabilir (Brown, 1997: 652). Bu anlamda çeşitli ulusal ve uluslararası kuruluşun oluşturduğu sıralama listeleri 
gösterilebilir, verdikleri ödüllere vurgu yapılabilir. Başarısızlık durumunda faaliyetlerinin sonuçları konusunda hesap verme tercih edilebilir. Bu doğrultuda sonuçları yeniden tanımlama ya da sonuçları gerekçelendirme yoluna gidilebilir (Asforth ve Gibbs, 1990: 181). Bu tip dönemlerde, krizlerin örgütsel meşruiyeti azaltıcı etkisinden dolayı (Massey, 2001: 154) hasarı en aza indirebilecek ve durumu atlatmaya yarayacak söylemler geliştirilebilir (Boyd, 2000: 346). Başarısızlık dış faktörlere bağlanabilir ya da durum rasyonelleştirilmeye çalışılabilir (Brown, 1997: 652). Bunu yaparken mantıklı, inanılır ve yeterince açık bir söylemde bulunulması gerekir (Elsbach, 1994: 83). Çünkü sonuçların uygun bir şekilde savunabilmesi (Suchman, 1995: 595) değerlendiricinin algısının istenilen yönde oluşmasının temel şartlarından biridir (Elsbach, 1994: 83). Kurumsal mantık ve otorite arasında dikkat çeken bir karşıtlık olduğu vurgusu ile problemi tanımlama ve çözüm sunma yolu tercih edilebilir (David vd., 2013: 371).

Değerlendiricinin normatif inançlarını yansıtan stratejiler: Bu stratejiler ortak olarak kabul edilen değerler (Suddaby ve Greenwood, 2005: 56), görgü kuralları (Sillince, 2005: 616) ortak hassasiyetler, kültürel açıklamalar, ortak deneyimler üzerine kuruludur (Bitektine ve Haack, 2015: 65). Normlara uygun eylem, ortak bir yaşama alanı oluşması konusunda görüş birliğine ulaşmaya oldukça katkı sağlar (Habermas, 2001: 37). Bu nedenle örgütler faaliyetlerini normatif yapı ve kurallara referans vererek savunursa daha ikna edici olacaklarını düşünür (Elsbach, 1994; 84). Çünkü sosyal normlar değerlendiricilerin çoğunluğu tarafından rasyonel olarak onaylanmış kuralları ifade eder (Habermas, 2001: 37). Bu kurallarla biçimlenmiş açıklama stratejileri meşru olarak görülür (DiMaggio ve Powell, 1991: 31). Eylem normları genel olduğu için haklı çıkarılabilir (Habermas, 2001: 37). Başarısızlık durumunda bile örgütler değerlendiricilere bu norm ve kuralları gösterebilir (Meyer ve Rowan, 1991: 51). Eylem normları herkesi ilgilendirmesi, dile getirilmesinin kolaylığı, kabul görme ihtimalinin yüksekliği ve hak iddia etmeye imkân verme özelliklerinden (Habermas, 2001: 38) dolayı sosyal geçerlilik alanlarında kullanılmaya oldukça elverişlidir. Bundan dolayı örgütler temel inanç, değer ve çıkarlarla uygunluğa vurgu yapmayı meşruiyet açısından önemli görür (Golant ve Sillince, 2007: 1153).

Varlığın kimliğini inşa eden stratejiler: Bu stratejiler aktörü kıymetlendirme ya da değersizleştirme üzerine kuruludur (Bitektine ve Haack, 2015: 65). Örgütler hem kendi hem de değerlendiricinin kimliğine vurgu yapmaya ya da onları yeniden tanımlamaya girişebilir. Sembol, değer ve kurumlar iletişim araçları sayesinde yeni bir kimlik oluşumuna katkıda bulunabilir (Dowling ve Pfefer, 1975: 127). Temel misyon açıklaması örgütün kimliğini ve varlık nedenini değerlendiricilere iletmek için en uygun araçlardan biri olarak kullanılabilir (Suchman, 1995: 588). Örgütün toplumdaki önemine vurgu yapılabilir (Asforth ve Gibbs, 1990: 189). Örgütlerin millilik, yerlilik, ideolojik, yaşam biçimlerine ve dünya görüşlerine yönelik vurguları değerlendiricide olumlu hükmün oluşmasına katkıda bulunabilir. Vaara ve Tienari (2011: 371) meşruiyet açıklamalarında küreselci, ulusalcı ve İskandinavcı şeklinde üç anlatı tipi tanımlamıştır. Creed vd., (2002: 494) sosyal kimlik ve kültürel açıklamalar arasında meşruiyet açısından karşıııklı ilişki olduğunu ifade eder. Glynn ve Abzug'a (2002: 267) göre örgütsel isimler, örgütün kimliği ve anlamın merkezi özelliklerini birleştirir. Örgütler şirketin adına ulusun ismini ekleyerek olumlu imaj oluşturabilir (Asforth ve Gibbs, 1990: 181) itibar, uygunluk ve meşruiyet elde edebilir (Glynn ve Abzug, 2002: 268).

Varlığın ahlaki değerlerine vurgu yapan stratejiler: Bu stratejiler değerlendiricinin sahip olduğu adalet (Tost, 2011: 690), etik, ahlak gibi değerler üzerine kuruludur (Bitektine ve Haack, 2015: 65). Örgütler faaliyet ve sonuçları değerlendiriciler tarafından görüş birliği sağlanmış ahlaki ilkeler üzerinden sunabilir (Habermas, 2001: 38). Ahlaki meşruiyet stratejisi, örgütler için 
somut ve değerli bir sonucun elde edilmesini sağlayabilir (Suchman, 1995: 588). Bu amaçla örgütler faaliyetleri hakkında ahlaki ve etik yorumlar yapabilir (Asforth ve Gibbs, 1990: 189). Bu durumda örgütün ahlaki statüsü meşruiyetin belirleyicisi olur. Vurgulanan etik ilkeler ve ahlaki argümanlar değerlendiricinin değerler sistemine uygunsa meşruiyet oluşur (Tost, 2011: 692). Ahlaki gerekçe kanıksanmış norm ve kurallara vurgu yaptığı için oldukça güçlüdür (Green, 2004: 660). Bu tip gerekçelerin dayandığı değerler özneler arası oldukları için evrensel olarak onaylanması beklenmese de (Habermas, 2001: 37) iletişim ve söylem yoluyla manipüle edilebilir oldukları söylenebilir (Green ve Li, 2011: 1672).

Duyguları yönlendiren stratejiler: Bu stratejiler acıma, korku, hırs, fedakârlık, iyilik gibi değerlendiricinin duygularına yöneliktir (Bitektine ve Haack, 2015: 65). Rasyonel ve mesleki örgütsel normlar nesnel ve savunulabilirdir. Oysaki söylem, normlara aykırı duygusal kavramlarla iletişimin güvenilirliğini zayıflatarak gerçekleştirilebilir (Asforth ve Gibbs, 1990: 190). Çünkü duygusal değerler yalnızca özel bir yaşam biçiminin bağlamında inandırıcı kılınabilir (Habermas, 2001: 67). Duyguların ortaya çıkması değerlendiricinin kendi ilgi dünyasıyla bağlantılıdır. Duygular değerlendiricinin sınırlı dikkatini uyandırmayı sağlar, hayal gücünü hareketlendirir ve davranışını etkiler (Green, 2004: 659). Bu nedenle örgütler yoksullara yardım, doğal afet, savaş ve göç mağdurlarına destek, spor, sanat, eğitim, kültür faaliyetlerinde sponsorluk gibi uygulamalarla meşruiyet elde etmeye çalışır (Asforth ve Gibbs, 1990: 181). Boxenbaum (2008: 239) çalışmasında, Quebec'deki firmaların gerçekleştirdiği sosyal sorumluluk projelerinin hem finansal hem de meşruiyete katkı gibi sosyal getirileri olduğunu göstermiştir.

Yukarıda örgütlerin uygulayabilecek oldukları geçerlilik ve uygunluk stratejileri örnekleriyle birlikte açıklanmaya çalışıldı. Geçerlilik stratejileri genelde bağlamın meşruiyetini kurucu ya da dağıtıcı bir etkiye sahipken, uygunluk stratejileri örgütün eylemlerini savunan ya da meydan okuyan bir etkiye sahiptir (Harmon vd., 2015: 77). Bu stratejilerin bütün değerlendiricilerde istenilen etkiyi üretmesi her zaman mümkün olmayabilir. Bunun temelde iki sebebi vardır. İlki, dilin kendinden, diğeri ise değerlendirici kitlesinin özelliğinden kaynaklanır. Öncelikle dil, anlamı aktarmayı mümkün kıldığı gibi aynı zamanda anlamı sınırlandıran bir özelliğe sahiptir (Brown ve Humphreys, 2006: 233). Dilde var olan sembol ve işaretlerin algısal doğası farklı anlamlara neden olabilir. İkinci neden ise değerlendiricilerin homojen olmamasıdır (Ridgeway ve Berger, 1986: 604-605). Hem farklı bireysel ve kolektif kimliklere sahiptirler (Brown ve Humphreys, 2006: 233) hem de beklenti ve ilgileri değişebilir (Suchman, 1995: 594). Kimlik ve şemalardaki farklııklar ile ilgi ve ilkelerdeki farklılıklar hem örgütün istediği anlamın değerlendiricide oluşmamasına hem de değerlendiriciler arasında farklı anlamların oluşmasına neden olabilir (Cornelissen vd., 2015: 12).

Stratejilerin istenilen sonucu üretebilmesinde genelde dört faktör etkilidir. Birincisi; söylemin anlamıdır. İkincisi; konuşmacının itibarının yüksekliğidir. Üçüncüsü; hedeflenen değerlendiricinin bir konsensüsü sergilemesidir. Dördüncüsü; zorlama ya da ikna için başvurulan kaynaktır (Bitektine ve Haack, 2015: 64). Söylemin anlamı oturmuş ve speküle edilebilir değilse, söyleyen kişi ya da örgüt alanda yüksek bir itibara sahipse, değerlendirici kitlesi konsensüse yatkınsa ve değerlendiriciyi ikna için yeterli gerekçeler üretilebilmişse stratejiler sonuç verebilir. Patriotta vd. de (2011: 1805) stratejilerin başarısı için üç koşulun oluşması gerektiğini belirtir. İlki, ortak iyi sosyal kabulle tutarlılık sağlamalıdır. İkincisi, diğer sosyal grupların ortak iyi tanımlarıyla uyumlu olmalıdır. Üçüncüsü, söylem ve gerekçe üretirken bağlama özgü etkin gerekçelendirmeler yapılmalıdır. 
Fakat örgütler açısından bir dilsel stratejinin başarısı yalnızca yukarıda değinilen unsurlara bağlı değildir. Bitektine ve Haack (2015: 50) mikro seviyede aktörlerin kurumsal değişimi nasıl gerçekleştirdiğini ve meşruiyet hükümlerinin nasıl alışıımışın dışına çıktığını göstermek için, kurumsal durağanlık ve kurumsal değişim şeklinde iki durum tanımlaması yapar. Bu tanımlama aslında Swidler'in (1986: 278-280) istikrarlı ve istikrarsız sosyal çevre ayrımından türetilmiştir. Hybels de (1995: 242-243) meşruiyet ile çevresel durağanlık ve değişkenlik arasında ilişki olduğunu vurgular. Bu nedenle değerlendiricilerin meşruiyet hükümlerinde değişkenlikten düzenliliğe nasıl dönüldüğünün, kurumsal değişimin sosyal dinamikleri üzerinden açıklanması sosyal analize daha uygundur. Bu nedenle meşru hükümlerin değişkenliği ve istikrarında iletişimin rolünü açıklama açısından kurumsal istikrar ve değişim şartları önemli etkenler olarak ele alınmalıdır (Bitektine ve Haack, 2015; 52). Ancak bu oldukça kapsamlı bir konu olduğu için başka bir çalışmada özellikle tartışılabilir. Bundan dolayı bu çalışmada bahsi geçen faktör ihmal edilmiş ve değerlendirmede dikkate alınmamıştır.

\section{Sonuç ve Değerlendirme}

Bu çalışmada, örgütlerin kurumsal yapıları kusursuz kanıksamadığı varsayımından hareket edilmekte ve örgütlerin çevrelerini söylem stratejileriyle manipüle edebildikleri ve böylelikle kurumsal çevreye gerçekte uyum sağlamasa bile meşruiyet kazanabildikleri iddia edilmektedir. Bunu kurumsallaşmış stratejiler olarak nitelenebilecek olan söylem stratejileri ile başarabildikleri öne sürülmektedir. Söylem stratejilerinin kurumsallaşmış olması gerektiği vurgulanmakta, aksi takdirde toplumsal çevre tarafından anlaşılamama ya da onaylanmama riskiyle karşılaşabileceği belirtilmektedir. Küresel örgütlerin yerel ve evrensel içerikli söylem stratejileri ise topluma özgü ve evrensel şemalar ayrımı ve örgütlerin çoklu şemalara sahip olabileceği değerlendirmesi ile açıklanmaya çalışılmıştır. Çoklu şema varsayımının örgütlere değişen durumlara göre farklı stratejiler kullanma imkânı tanıdığı öne sürülmüştür.

Bu çoklu şemalar sayesinde örgüt bir yandan farklı kültürel ve kurumsal çevrelerde geliştirdiği farklı söylemlerle meşruiyet elde edebilirken diğer yandan bireysel değerlendiricilerde uygunluk hükmü, kolektif değerlendiricilerde geçerlilik hükmü oluşturarak iki ayrı seviyede de meşruiyeti kazanabilmektedir. Bireysel değerlendiricilerin kolektif hükümlerden, kolektif değerlendiricilerin ise bireysel hükümlerden etkilendikleri görüşü son derece gerçekçi olmasına rağmen bireysel hükümlerin kolektif hükme dönüşümünün meşruiyet stratejileri konusunda zamansal açıdan birçok zorluk içerdiği ve kolaylıkla gösterilemeyeceği söylenebilir. Bu nedenle bireysel ve kolektif değerlendiricileri ayrı bir şekilde ele alan fakat bunlar arasındaki ilişkiye de değinmeyi ihmal etmeyen çoklu seviye meşruiyet analizinin bu tip çalışmalar için daha uygun olduğu düşünülmektedir.

Örgütler aslında bireysel, örgütsel ve kurumsal seviyede ayrı ayrı söylem stratejileri geliştirmeseler bile genellikle kurumsal ve kültürel çevre unsurlarını kullandıkları ve bu sayede bir yandan amaçlarını gizlerken diğer yandan da o amaca ulaşabildikleri öne sürülebilir. Özellikle modern dönemlerde örgütlerin kendi dışındaki varlıkların da temsili rolünü üstlenebilmesinin meşruiyet süreçlerini daha rahat rasyonelleştirebilmesine imkân tanıdı. Oluşan bu sosyal ortam bilişsel, ahlaksal, değersel ve duygusal argümanlarla örgütlerin yapı ve faaliyetlerini gerekçelendirmesini kolaylaştırdı. Şartlara ve çevreye göre değişen gerekçelerden oluşan bu söylem stratejilerinin etkisi kurumsal alanın istikrarlı olduğu durumlarda farklı, değişken olduğu durumlarda farklı etkiler üretecektir. Fakat bu durum çalışmanın iki araştırma sorusuna verilen cevabı değiştirmeyecektir. Bu doğrultuda çalışmanın birinci araştırma sorusunu oluşturan, "örgütsel dil örgütsel meşruiyetin oluşumunda rol oynar mı?” sorusuna çalışmanın cevabı, "örgütsel dil 
stratejileri değerlendiriciler üzerinde manipülayon yapma ve hüküm oluşturma potansiyeline sahip olduğundan dolayı örgütsel meşruiyetin oluşumunda rol oynar" şeklindedir. Çalışmanın ikinci araştırma sorusu olan "örgütsel dilin örgütsel meşruiyetin oluşumunda rol oynadığı iddiası kurumsal kuramla çelişir mi?" sorusuna cevabı ise, "örgütsel dil stratejileri kurumsal stratejiler olduğu için bu iddia kurumsal kuramla çelişmez" şeklindedir. 


\section{Eskişehir Osmangazi Üniversitesi iiBF Dergisi}

\section{Kaynaklar}

Aldrich, H. and Fiol, C. M. (1994). Fools rush in? The institutional context of industry creation. Academy of Management Review, 19(4), 645-670.

Ashforth, B. E. and Gibbs, B. W. (1990). The double-edge of organizational legitimation. Organization Science, 1(2), 177-194.

Bansal, P. and Clelland, I. (2004). Talking trash: Legitimacy, impression management and unsystematic risk in the context of the natural environment. Academy of Management Journal, 47 (1), 93-103.

Berger, J., Ridgeway, C., Fisek, M. H. and Norman, R. Z. (1998). The legitimation and delegitimation of power and prestige orders. American Sociological Review, 63, 379-405.

Bitektine, A. (2011). Toward a theory of social judgments of organizations: The case of legitimacy, reputation and status. Academy of Management Review, 36(1), 151-179.

Bitektine, A. and Haack, P. (2015). The "macro" and the "micro" of legitimacy: Toward a multilevel theory of the legitimacy process. Academy of Management Review, 40(1), 49-75.

Boje, D.M., Oswick, C. and Ford, J.D. (2004). Language and organization: the doing of discourse. Academy of Management Review, 29(4), 571-577.

Boxenbaum, E. (2008). The process of legitimation. In Scheuer, S. and Schewer, J.D.(Eds) The anatomy of change. 237262. CBS Press.

Boyd, J. (2000). Actional legitimacy: No crisis necessary. Journal of Public Relations Research, 4, 341-353.

Brown, A.D. (1997). Narcissism, idendity and legitimacy. Academy of Management Review. (22)3, 643-686.

Brown, A.D. and Humphreys, M. (2006). Organizational identy and place: A discoursive exploration of hegemony and resistance. Journal of Management Studies, 43(2), 231-257.

Collins, R. (1981), On the microfoundations of macrosociology. American Journal of Sociology, 86(5), 984-1014.

Cornelissen, J. P., Durand, R., Fiss, P. C., Lammers, J. C. and Vaara, E. (2015). Putting communication front and center in institutional theory and analysis. Academy of Management Review, 40(1), 10-27.

Creed, W. E. D., Scully, M. A. and Austin, J. R. (2002). Clothes make the person? The tailoring of legitimating accounts and the social construction of identity. Organization Science, 13(5), 475-496.

David, R. J., Sine, W. D. and Haveman, H. A. (2013). Seizing opportunity in emerging fields: How institutional entrepreneurs legitimated the professional form of management consulting. Organization Science, 24(2), 356-377.

Deephouse, D. L. (1996). Does isomorphism legitimate?. Academy of Management Journal, 39(4), 1024-1039.

Deephouse, D.L. and Carter, S.M. (2005). An examination of differences between organizational legitimacy and organizational reputation. Journal of Management Studies, 42(2), 329-360.

DiMaggio, P. J. and Powell, W. W. (1991). Introdiction. In Powell, W.W. and DiMaggio, P.J. (Eds) The new institutionalism in organizational analysis. 1-38. University of Chicago Press. Chicago.

DiMaggio, P. J. (1997). Culture and cognition. Annual Review of Sociology, 23, 263-287.

Dowling, J. and Pfeffer, J. (1975). Organizational legitimacy: Social values and organizational behavior. Pacific Sociological Review, 18(1), 122-136.

Elsbach, K. D. and Sutton, R. I. (1992). Acquiring organizational legitimacy through illegitimate actions: A marriage of institutional and impression management theories. Academy of Management Journal, 35(4), 699-738.

Elsbach, K. D. (1994). Managing organizational legitimacy in the California cattle industry: The construction and effectiveness of verbal accounts. Administrative Science Quarterly, 39, 57-88.

Etzion, D. and Ferraro, F. (2010). The role of analogy in the institutionalization of sustainability reporting. Organization Science, 21(5), 1092-1107.

Fligstein, N. (1997). Social skill and institutional theory. American Behavioral Scientist, 40(4), 397-405.

Friedland, R. and Alford, R.R. (1991). Bringing society back in: Symbols, practies ve institutional contradictions. In Powell, W.W. and DiMaggio, P.J. (Eds) The new institutionalism in organizational analysis.232-263. University of Chicago Press. Chicago.

Giddens, A. (1984). The constitution of society: Autline of the theory of structuration. University of California Press, Berkeley and Los Angeles. 
Glynn, M. A. and Abzug, R. (2002). Institutionalizing identity: Symbolic isomorphism and organizational names. The Academy of Management Journal, 45(1), 267-280.

Glynn, M. A. and Navis, C. (2013). Categories, identities and cultural classification: Moving beyond a model of categorical constraint. Journal of Management Studies, 50(6), 1124-1137.

Golant, B. D. and Sillince, J. A. A. (2007). The constitution of organizational legitimacy: A narrative perspective. Organization Studies, 28(8), 1149-1167.

Granovetter, M. (1985). Economic action and social structure. The problem of embeddedness. American Journal of Sociology, 91(3), 481-510.

Grant, D., Keenoy, T. and Oswick, C. (2001). Organizational discourse. International Studies of Management and Organization, 31(3), 5-24.

Green, S. E. (2004). A rhetorical theory of diffusion. Academy of Management Review, 29(4), 653-669.

Green, S. E., Li, Y. and Nohria, N. (2009). Suspended in self-spun webs of significance: A rhetorical model of institutionalization and institutionally embedded agency. Academy of Management Journal, 52(1), 11-36.

Green, S. E. and Li, Y. (2011). Rhetorical institutionalism: Language, agency and structure in institutional theory since Alvesson 1993. Journal of Management Studies, 48(7), 1662-1697.

Haack, P., Pfarrer, M. D. and Scherer, A. G. (2014). Legitimacy as feeling: How affect leads to vertical legitimacy spillovers in transnational governance. Journal of Management Studies, 51(4), 634-666.

Habermas, J. (2001). İletişimsel Eylem Kuramı. (Çev. Mustafa Tüzel), Kabalcı Yayınevi, İstanbul.

Hardy, C. and Maguire, S. (2010). Discourse, field-configuring events and change in organizations and institutional fields: Narratives of DDT and the Stockholm convention. Academy of Management Journal, 53(6), 1365-1392.

Harmon, D. J., Green, S. E. and Goodnight, G. T. (2015). A model of rhetorical legitimation: The structure of communication and cognition underlying institutional maintenance and change. Academy of Management Review, 40(1), 76-95.

Hasselbladh, H. and Kallinikos, J. (2000). The Project of rationalization: A critique and reappraisal of neo-istitutionalism in organization studies. Organization Studies, 21(4), 697-720.

Heracleous, L. and Barrett, M. (2001). Organızational change as discourse: Communicative actions and deep structures in the context of information technology implementation. Academy of Management Journal. 44(4) 755-778.

Heracleous, L. and Marshak, R.J. (2004). Organizational discourse as situated symbolic action: Application through and intervention. Academy of Management Best Conference Paper, ODC, 1-6.

Hirsch, P.M. (1997). Sociology without social structure: Neo-institutional theory meets brave new World. American Journal of Sociology, 102(6), 1702-1723.

Hybels, R.C. (1995) On legitimacy, legitimation, and organizations: A critical review and integrative theoretical model. Academy of Management Best Papers Proceedings, 241-245.

Jepperson, R.L. (1991). Institutions, institutional effects and institutionalism. In Powell, W.W. and DiMaggio, P.J. (Eds) The new institutionalism in organizational analysis.143-163. University of Chicago Press. Chicago.

Jepperson, R.L. and Meyer, J.W. (1991). The puclic order and the construction of formal organization. In Powell, W.W. and DiMaggio, P.J. (Eds) The new institutionalism in organizational analysis.204-231. University of Chicago Press. Chicago.

Jepperson, R.L. and Meyer, J.W. (2011). Multiple levels of analysis and the limitations of methodological individualisms sociological theory, 29(1), 54-73.

Johnson, C., Dowd, T. J. and Ridgeway, C. L. (2006). Legitimacy as a social process. Annual Review of Sociology, 32, 5378.

Kraatz, M. S. and Zajac, E. J. (1996). Exploring the limits of the new institutionalism: The causes and consequences of illegitimate organizational change. American Sociological Review, 61(5), 812-836.

Lawrence, T. B. (1999). Institutional strategy. Journal of Management, 25(2), 161-188.

Lawrence, T.B. and Phillips, N. (2004). From moby dick to free willy: Macro-cultural discourse and institutional entrepreneurship in emerging institutional fields. Organization, 11(5), 689-711.

Leeuwen, T. V. and Wodak, R. (1999). Legitimizing immigration control: A discourse historical analysis. Discourse Studies, 1(1), 83-118. 


\section{Eskişehir Osmangazi Üniversitesi iiBF Dergisi}

Lounsbury, M. and Glynn, M.A. (2001). Cultural entrepreneurship: Stories, legitimacy and the acquisition of resources. Strategic Management Journal, 22, 545-564.

Massey, J. E. (2001). Managing organizational legitimacy: Communication strategies for organization in crisis. Journal of Business Communication, 38(2), 153-183.

Mazza, C. (1999). Claim, intent, and persuasion: Organizational legitimacy and the rhetoric of corporate mission statements. Springer Science-Business Media.

Meyer, J.W. and Rowan, B. (1977). Institutionalized organizations: Formal structure as myth and ceremony . The American Journal of Sociology, (83)2, 340-363.

Meyer, J.W. and Rowan, B. (1991). Institutionalized organizations: Formal structure as myth and ceremony . In Powell, W.W. and DiMaggio, P.J. (Eds) The new institutionalism in organizational analysis.41-62. University of Chicago Press. Chicago.

Meyer, J. W. and Jepperson, R. L. (2000). The actors of modern society: The cultural construction of social agency, Sociological Theory, 18(1), 101-120.

Meyer, J.W. (2008). Reflections on institutional theories of organizations. In Greenwood, R., Oliver, C., Suddaby, R. and Andersson, K.S., (Eds.). Handbook of organizational institutional. 788-809. Sage.

Meyer, J. W. (2010). World society, institutional theories, and the actor. Annual Review of Sociology, 36, 1-20.

Navis, C. and Glynn, M. A. (2010). How new market categories emerge: Temporal dynamics of legitimacy, identity and entrepreneurship in satellite radio, 1990-2005. Administrative Science Quarterly, 55(3), 439-471.

Oakes, L. S., Townley B. and Cooper, D. J. (1998). Business planning as pedagogy: Language and control in a changing institutional field. Administrative Science Quarterly, 43, 257-292.

Oliver, C. (1991). Strategic responses to institutional processes. The Academy of Management Review, 16(1), 145179.

Oliver, C. (1992). The antecedents of deinstitutionalization. Organization Studies, 13(4), 563-588.

Patriotta, G., Gond, J. P. and Schultz, F. (2011). Maintaining legitimacy: Controversies, orders of worth and public justifications. Journal of Management Studies, 48(8), 1804-1836.

Phillips, N., Lawrence, T.B., and Hardy, C. (2004). Discourse and institutions. Academy of Management Review, 29(4), 635-652.

Phillips, N. and Oswick, C. (2012). Organizational discourse: Domains, debates, and directions. Academy of Management Annals, 6(1), 435-481.

Pollock, T. G. and Rindova, V. P. (2003). Media legitimation effects in the market for initial public offerings. Academy of Management Journal, 46(5), 631-642.

Powell, W.W. (1991). Expanding the scope of institutional analysis. In Powell, W.W. and DiMaggio, P.J. (Eds) The new institutionalism in organizational analysis.183-203. University of Chicago Press. Chicago.

Powell, W. W. and Colyvas, J. A. (2008). Microfoundations of institutional theory. In R. Greenwood, C. Oliver, K. Sahlin, and R. Suddaby (Eds) The Sage handbook of organizational institutionalism, 276-298. London: Sage.

Ridgeway, C. L. and Berger, J. (1986). Expectations, legitimation and dominance behavior in task groups. American Sociological Review, 51(5), 603-617.

Ruef, M. and Scott, W. R. (1998). A multidimensional model of organizational legitimacy: Hospital survival in changing institutional environment. Administrative Science Quarterly, 43(4), 877-904.

Scott, W.R. (1991). Unpacking institutional arguments. In Powell, W.W. and DiMaggio, P.J. (Eds) The new institutionalism in organizational analysis.164-182. University of Chicago Press. Chicago.

Scott, W.R. (2008). Approaching adulthood: The maturing of institutional theory. Theory Sociology. 37, 427-442.

Searle, J.R. (2005). Toplumsal Gerçekliğin İnşası. (Çev. Muhittin Macit ve Ferruh Özpilavcı), Litera Yayıncılık, İstanbul.

Sewell, W. H. (1992). A theory of structure: Duality, agency and transformation. American Journal of Sociology, 98(1), 1-29.

Sillince, J.A. (2005). A contingency theory of rhetorical congruence. Academy of Management Review, 30(3), 608-621.

Strang, D. and Bradburn, E.M. (2001). Theorizing legitimacy or legitimating theory? Neoliberal discourse and HMO policy, 1970-1989. In The second movement in institutional analysis. neoliberalizm in perspective, Princeton: Princeton University Press. 
Stryker, R. (1994). Rules, resources and legitimacy processes: Some implications for social conflict, order and change. American Journal of Sociology, 99, 847-910.

Suchman, M. (1995). Managing legitimacy: Strategic and institutional approaches. Academy of Management Review, 20, 571-610.

Suddaby, R. and Greenwood, R. (2005). Rhetorical strategies of legitimacy. Administrative Science Quarterly, 50(1), 35-67.

Swidler, A. (1986). Culture in action: Symbols and strategies. American Sociological Review, 51(2), 273-286.

Tolbert, P. S. and Zucker, L. G. (1996). The institutionalization of institutional theory. In Clegg, S., Hardy, C. and Nord, W. (Eds.), Handbook of organization studies.175-190. London: Sage.

Tost, L. P. (2011). An integrative model of legitimacy judgments. Academy of Management Review, 36(4), 686-710.

Vaara, E., Tienari, J. and Laurila, J. (2006). Pulp and paper fiction: On the discursive legitimation of global industrial restructuring. Organization Studies, 27(6), 789-810.

Vaara, E. and Tienari, J. (2008). A discursive perspective on legitimation strategies in multinational corporations. Academy of Management Review, 33(4), 985-993.

Vaara, E. and Monin, P. (2010). A recursive perspective on discursive legitimation and organizational action in mergers and acquisitions. Organization Science, 21(1), 3-22.

Vaara, E. and Tienari, J. (2011). On the narrative construction of multinational corporations: An antenarrative analysis of legitimation and resistance in a cross-border merger. Organization Science, 22(2), 370-390.

Waeraas, A. and Ihlen, Q. (2009). Green legitimation: The construction of an environmental ethos. International Journal of Organizational Analysis, 17(2), 84-102.

Westphal, J. D., Gulati, R. and Shortell, S. M. (1997). Customization or conformity? An institutional and network perspective on the contentand consequences of TQM adoption. Administrative Science Quarterly, 42(2), 366-394.

Wiley, N. (1988). The micro - macro problem in social theory. Sociological Theory, 6(2), 254-261.

Woodward, D. G., Edwards, P. and Birkin, F. (1996). Organizational legitimacy and stakeholder information provision. British Journal of Management, 7, 329-347.

Zbaracki, M. J. (1998). The rhetoric and reality of total quality management. Administrative Science Quarterly, 43, 602-636.

Zelditch, M. J. (2001). Processes of legitimation: Recent developments and new directions. Social Psychology Quarterly, 64, 4-17.

Zimmerman, M. A. and Zeitz, G. J. (2002). Beyond survival: Achieving new venture growth by building legitimacy. The Academy of Management Review, 27(3), 414-431.

Zucker, L.G. (1991). The role of institutionalization in cultural persistence. In Powell, W.W. and DiMaggio, P.J. (Eds) The new institutionalism in organizational analysis. 83-107. University of Chicago Press. Chicago. 
Eskişehir Osmangazi Üniversitesi iiBF Dergisi 